\title{
De-globalization: Theories, predictions, and opportunities for international business research
}

\section{Michael A. Witt}

INSEAD, 1 Ayer Rajah Avenue, Singapore 138676, Singapore

\section{Correspondence:}

MA Witt, INSEAD, 1 Ayer Rajah Avenue, Singapore 138676, Singapore. Tel: +65-6799-5253;

e-mail: michael.witt@insead.edu

\begin{abstract}
De-globalization, now a distinct possibility, would induce a significant qualitative shift in strategies, structures, and behaviors observable in international business (IB). Coming to terms with this qualitative shift would require IB research to develop a much deeper integration of politics, the key driver of de-globalization. To support such integration, this paper introduces two relevant theories of (de-)globalization from political science, liberalism and realism. Both predict de-globalization under current conditions but lead to different expectations about the future world economy: liberalism suggests a patchwork of economic linkages, while realism predicts the emergence of economic blocs around major countries. This paper discusses the resulting opportunities in three areas of IB research: political strategies and roles of multinational enterprises (MNEs), global value chains, and the role of the national context. For political strategies and roles, there is a need to explore how regular business activities and deliberate political agency of MNEs affect the political sustainability of globalization. For value chains, questions include their future reach and specialization, changes in organizational forms, and the impact of political considerations on location decisions. Research opportunities on national contexts relate to their ability to sustain globalization and their connection with economic and military power.
\end{abstract}

Journal of International Business Studies (2019) 50, 1053-1077. https://doi.org/10.1057/s41267-019-00219-7

Keywords: globalization; internationalization theory; international relations and political science; political backlash; global institutions; trade blocs; political strategies; global supply chain strategies; institutional context

The online version of this article is available Open Access

\section{INTRODUCTION}

Growing evidence suggests that we may live in a period of deglobalization that began a decade ago. As I will show, trade globalization seems to have peaked between 2007 and 2010, and foreign direct investment (FDI) globalization between 2007 and 2011. Greater restrictions on trade and investments have accompanied these developments.

For a field like International Business (IB) that has been built on an implicit assumption of ongoing globalization, de-globalization
Received: 1 December 2017

Revised: 7 January 2019

Accepted: 9 January 2019

Online publication date: 4 April 2019 
would mark a significant turn of events. What are the implications for the stock of knowledge that IB has evolved over the past decades? Assuming deglobalization is real and persistent, will we see the same structures, behaviors, and strategies as before, merely at lower levels of scale and scope? Or will significant aspects of international business be qualitatively different, requiring new theorizing and empirical exploration?

I argue that the latter, a qualitative shift, would be likely in a de-globalizing environment, and that coming to terms with this shift would require a much deeper integration of politics in IB theory and research.

The centrality of politics stems from its role as a key driver of (de-)globalization. While technology and resultant drops in the costs of transportation and communication may enable globalization, politics determines whether firms and individuals can take advantage of the opportunities thus afforded (Chase-Dunn, Kawano, \& Brewer, 2000; Jones, 2007; O'Rourke \& Williamson, 2014). Accordingly, the previous wave of globalization broke down in the first half of the twentieth century not because of technological regression (O'Rourke \& Williamson, 2014). Rather, as a comprehensive body of historical exploration across the social sciences has documented, it ended because governments stepped in to curtail trade and capital flows for geopolitical and domestic reasons (ChaseDunn et al., 2000; Findlay \& O'Rourke, 2003; Jones, 2005, 2007, 2014; Kindleberger, 1973; Meyer, 2017; O'Rourke \& Williamson, 2014). Academy of International Business annual meetings, calls for special issues on de-globalization from the Global Strategy Journal and Strategy Science, and first IB publications on the topic (Kobrin, 2017; Meyer, 2017) all suggest that IB scholars are keenly aware of the role of politics. However, much of the debate has been empirically based rather than informed by theory.

Relevant theory, however, does exist: in the International Relations field of political science. There, two major competing schools of thought, liberalism ${ }^{1}$ and realism, have sought to account for the development of globalization, each pointing to different mechanisms driving it and leading to its reversal. Liberalism identifies domestic political pressures against globalization as a cause of deglobalization, a narrative that is consistent with much public debate. Realism, on the other hand, sees the end of US hegemony and the rise of China as a geostrategic competitor as the trigger. The two theories point to different scenarios for the future of the world economy, with different implications for future IB research. In particular, they suggest that significant aspects of multinational enterprise (MNE) activities under de-globalization will be qualitatively different from what we have seen so far.

In what follows, I begin by defining de-globalization and showing data suggesting that de-globalization may already be a reality. I then introduce the two relevant major bodies of theory from political science, liberalism and realism. While further schools of thought exist, the present pair represent the current mainstream. For each theory, I lay out the general mechanisms, the specifics of how the theory would account for (de-)globalization, and the outcomes for a de-globalizing world the theory suggests. It will become clear that these theories not only vary considerably in the mechanisms they see at work but also in their predictions of what a de-globalizing world would look like.

I then discuss implications of the two theories for IB research with respect to three major IB topics: the political strategies and roles of MNEs, global value chains, and interaction with the national context. After a brief summary, I conclude with thoughts on the importance and appropriateness of integrating international politics into IB.

\section{THE STATE OF DE-GLOBALIZATION}

Globalization is commonly defined in IB as the process of increasing interdependence among nations (Chase-Dunn et al., 2000; Guillén, 2001; Meyer, 2017; Rugman \& Verbeke, 2004; Verbeke, Coeurderoy, \& Matt, 2018). Accordingly, de-globalization represents the process of weakening interdependence among nations. While (de-)globalization has multiple facets, the focus of this paper is on the economic realm.

Importantly, the level of analysis is the world, not the individual nation (Chase-Dunn et al., 2000). Just as globalization does not require that every single nation become more interdependent for instance, North Korea arguably moved against the trend by becoming less interdependent after the end of the Cold War - de-globalization does not require that every single country become less interdependent. Indicative of globalization or deglobalization is what happens in the world as a whole.

At the global level, de-globalization seems to have been in progress for several years, at least with respect to the dimensions most directly relevant to 
International Business, trade and FDI. A weakening of interdependence for these two dimensions means that we should observe that, on average, countries rely less on goods and services or on investment from other countries, relative to levels of domestic economic activity. In other words, trade and investment flows as percentages of GDP should be declining.

The data are consistent with this expectation. In terms of trade, Figure 1 shows a time series of world average levels of imports of goods and services as a percentage of GDP, weighted by GDP (World Bank, 2018). It suggests that the period of rapid growth from around 1985 onwards peaked in 2007 at $30.2 \%$ before dropping as a result of the 2007 financial crisis. It rebounded in 2009 and 2010, reaching $30.1 \%$, but has since been on a slight downward trend.

A similar but more pronounced downward trend is visible in FDI. Figure 2 shows a time series of world average levels of inward FDI flows as a percentage of GDP, weighted by GDP (World Bank, 2017). After a rapid increase in the 1990s, this measure first peaked at $4.4 \%$ with the burst of the dotcom bubble; it recovered from 2004 onwards and peaked again in 2007 at $5.3 \%$ before falling as a result of the 2007 financial crisis. It has since stabilized between 2 and 3\%. Importantly, these changes are not accounted for by equivalent drops in overall investment levels (World Bank, 2018).

These numbers are vulnerable to a number of distortions (Chase-Dunn et al., 2000). In particular, they rely on currency conversion to US dollars in the weighting by GDP and need adjusting for inflation. The usual correction mechanisms for these issues, purchasing power parities (PPP) and constant prices, are themselves estimates that are vulnerable to estimation and measurement errors. For instance, the 2011 corrections of PPP exchange rates in the Penn World Tables resulted in China's economy "growing" by $27 \%$ in 2005 (Subramanian, 2011).

As a robustness test, I consequently followed Chase-Dunn et al. (2000) and weighted imports as well as foreign direct investment by population. Figures 3 and 4 show the results. They are broadly consistent with those produced by weighting by GDP, especially with respect to the recent declining trends. Obviously, these measures are subject to different distortions. For instance, China and India are much more heavily weighted, which accounts for the absence of a peak in 2000 in Figure 4.

Additional alternative measures draw a consistent picture for both globalization outcomes and changes in trade and investment regulations underpinning them. The KOF Globalization Index (Dreher, 2006; Dreher, Gaston, \& Martens, 2008; Gygli,

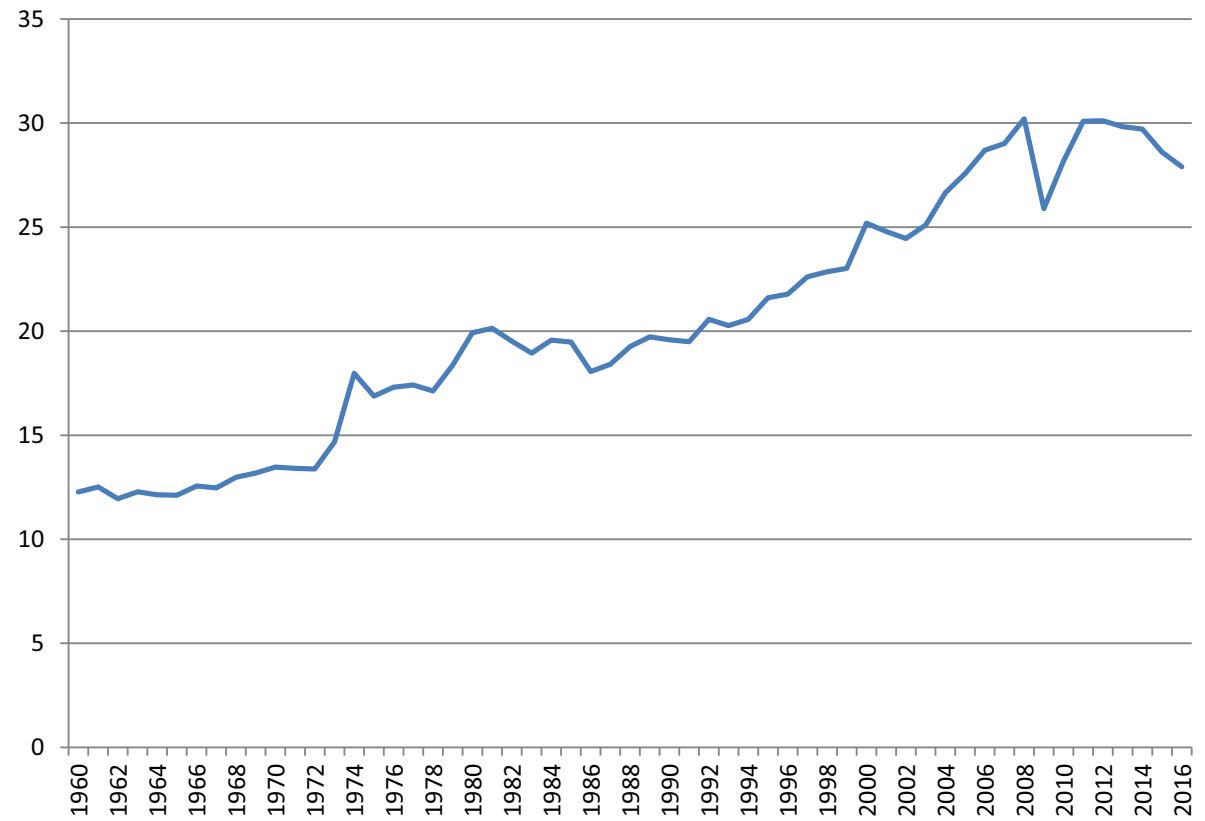

Figure 1 World average levels of imports of goods and services as a percentage of GDP, weighted by GDP. Source: World Bank (2018). 


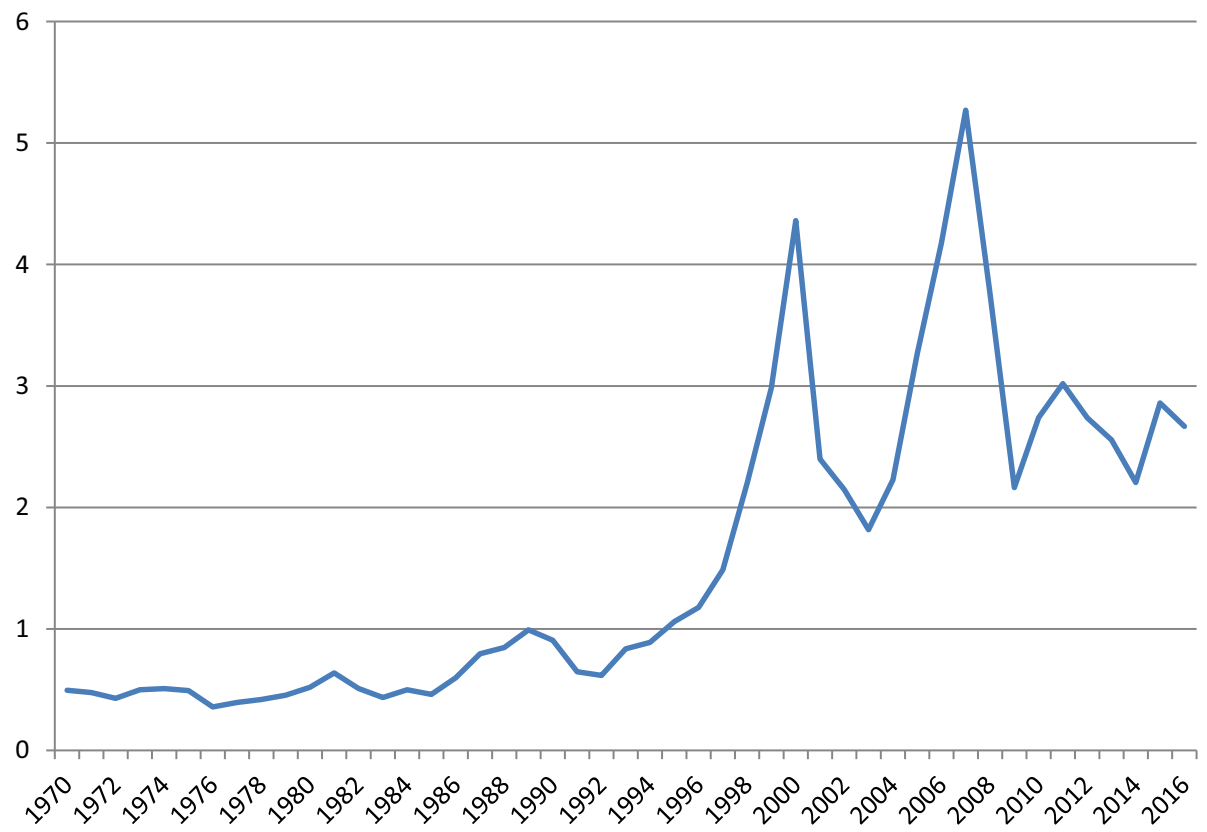

Figure 2 World average levels of inward FDI flows as a percentage of GDP, weighted by GDP. Source: World Bank (2017).

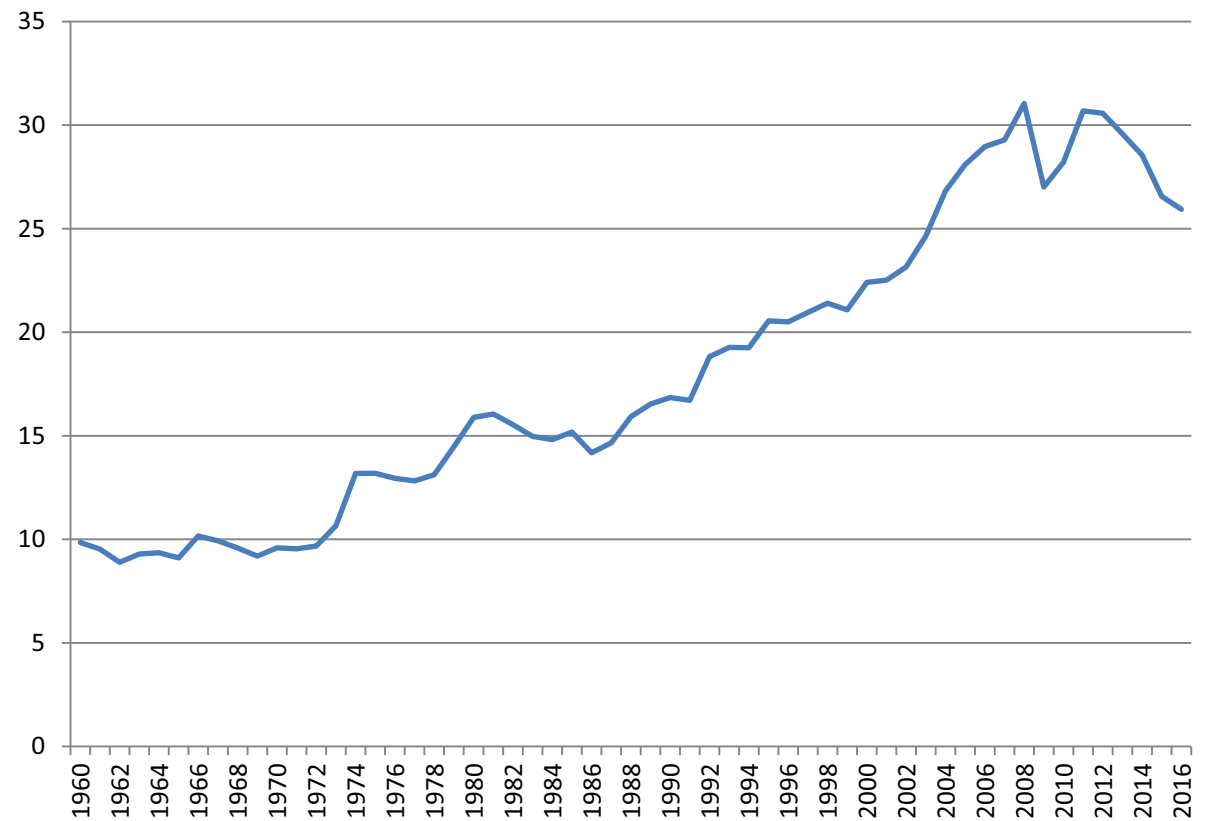

Figure 3 World average levels of imports of goods and services as a percentage of GDP, weighted by population. Source: World Bank (2017).

Haelg, \& Sturm, 2018) provides sub-indices of de facto and de jure trade globalization, with the latter reflecting changes in the regulatory environment. Figure 5 shows the timeline of these measures from 1970 to 2015 , the last year for which the indices are currently available. De facto trade globalization peaked in 2008, and de jure trade globalization, in 2010.

While the KOF Globalization Index provides only a composite financial globalization index incorporating both direct and portfolio investments, it is possible to gain insights into the FDI dimension by drawing on the underlying data. For de facto FDI 


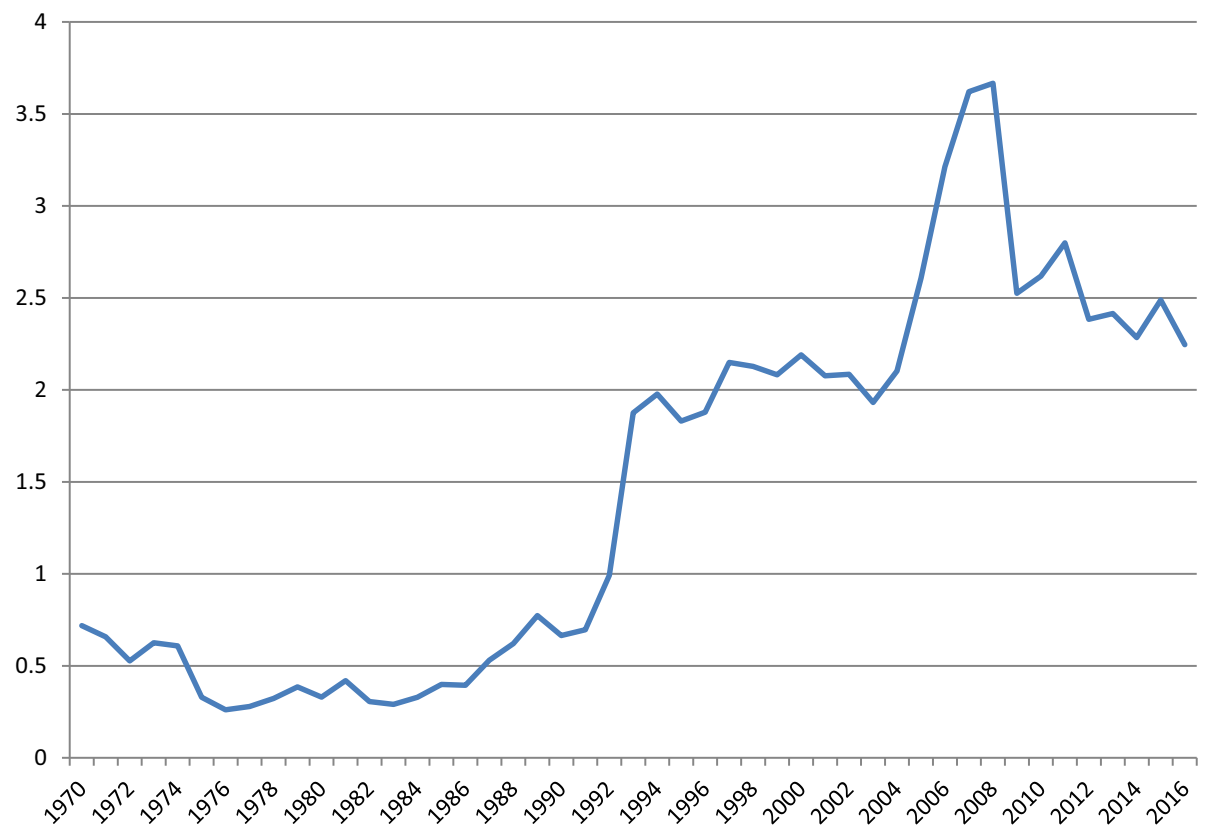

Figure 4 World average levels of inward FDI flows as a percentage of GDP, weighted by population. Source: World Bank (2017).

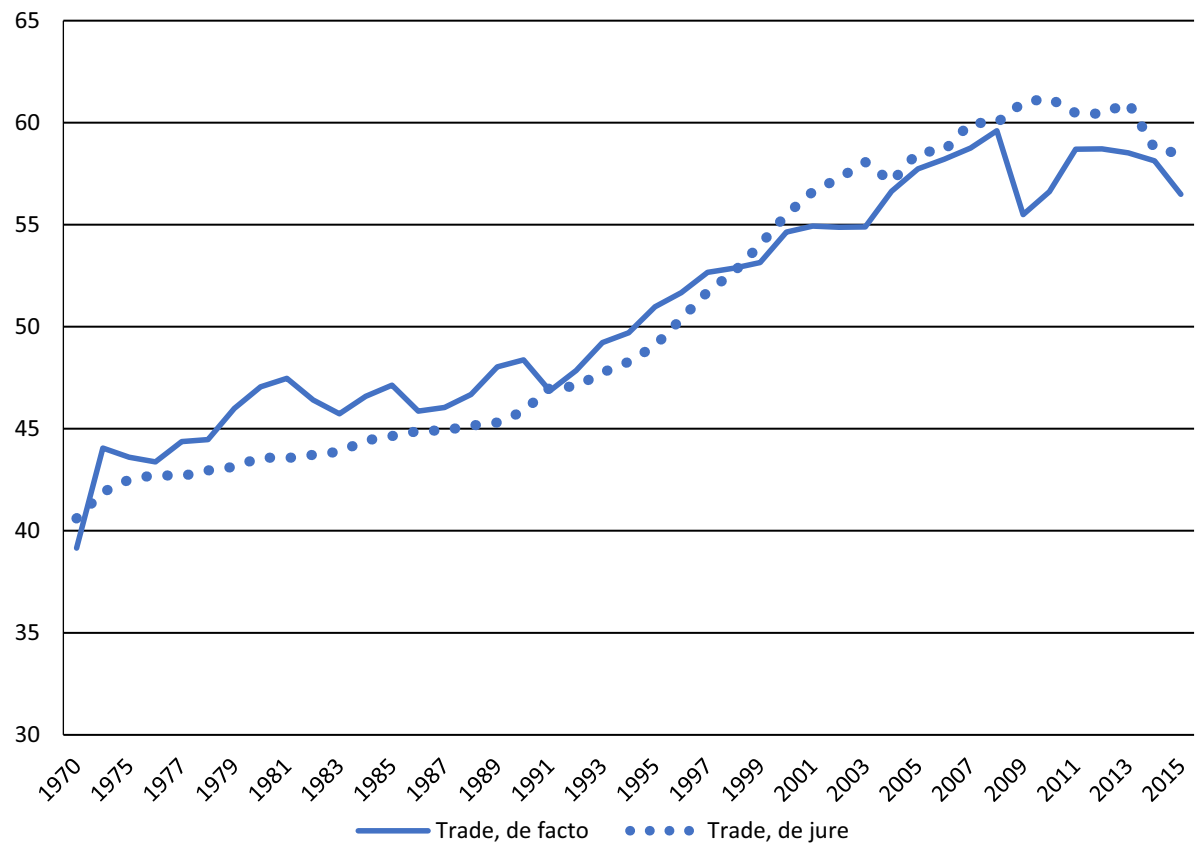

Figure 5 KOF Globalization Index, sub-indices for de facto and de jure trade globalization. Source: KOF Swiss Economic Institute (2018).

globalization, the composite financial globalization index uses IMF data on the net position of foreign direct investment stocks standardized by GDP. As Figure 6 shows, this measure, too, is consistent with the possibility of ongoing de-globalization, with a considerable drop since its peak in 2011.

For de jure FDI globalization, the KOF Globalization Index draws on the investment restrictions variable of the Economic Freedom Index. Figure 7 


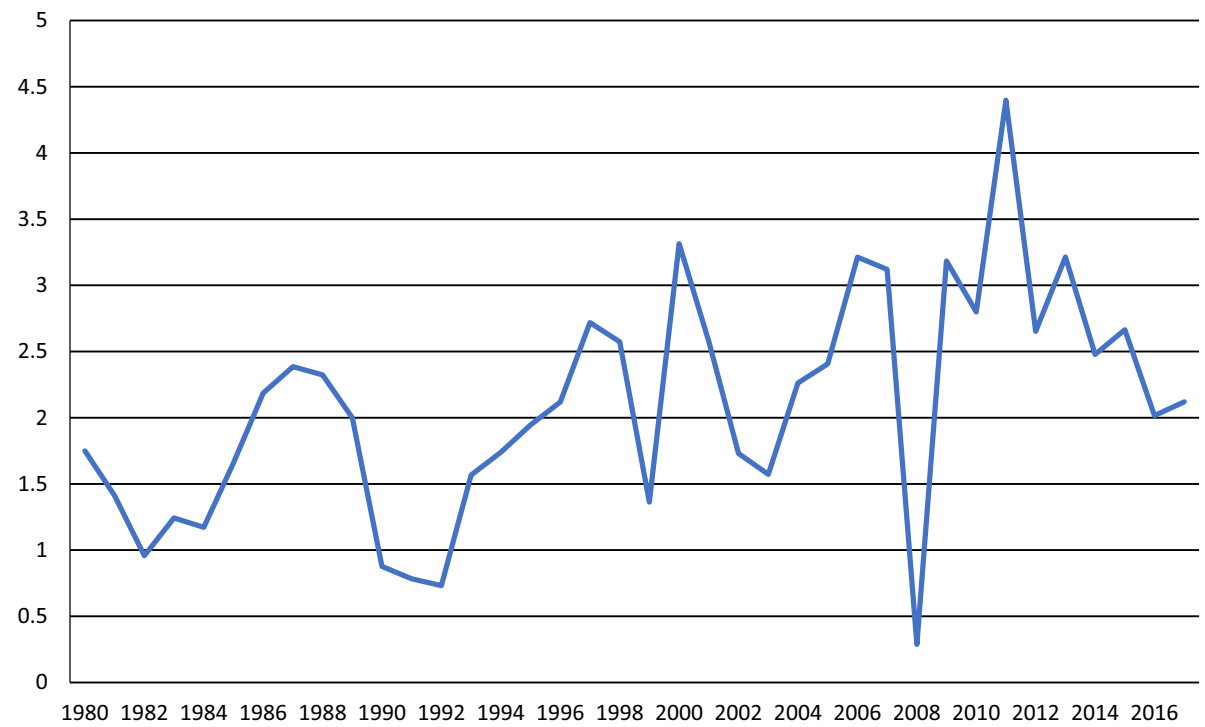

Figure 6 World net foreign direct investment position as percentage of world GDP. Years before 1980 not available. Source: IMF (2018a, b).

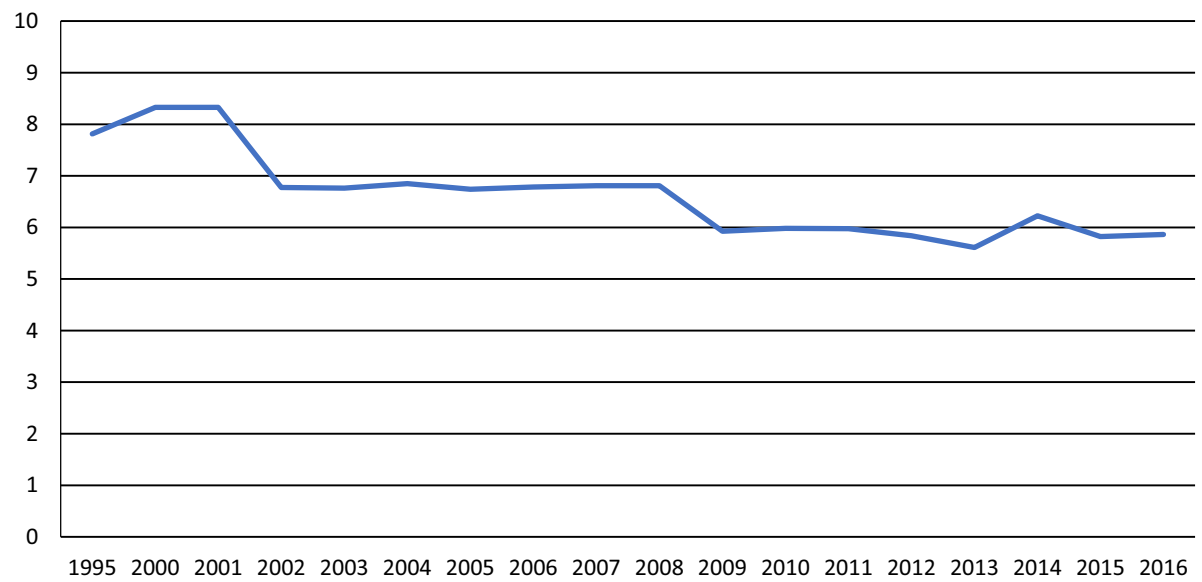

Figure 7 Foreign ownership/investment restrictions. Higher = fewer restrictions. Years before 1995 and from 1996 to 1999 not available. Source: Fraser Institute (2018).

shows the trend in this variable since 1995, the earliest year for which the variable is available in the dataset (Fraser Institute, 2018). Since higher values indicate more economic freedom, the figure suggests that de jure FDI globalization peaked in 2000/2001 and has shown a declining trend since.

Overall, while these statistics do not constitute conclusive proof, they are consistent with a shift towards lower levels of economic interdependence, and thus with de-globalization. This is particularly remarkable considering that technology has continued to improve, a development that at least in the past and all else equal facilitated higher levels of economic interdependence (Chase-Dunn et al., 2000; Jones, 2007). ${ }^{2}$

\section{DE-GLOBALIZATION: EXPLANATIONS AND POSSIBLE OUTCOMES}

As mentioned in the introduction, politics is a key factor in both globalization and de-globalization. The field of International Relations in political science has developed two major theoretical approaches ${ }^{3}$ that speak to the question of (de-)globalization: liberalism and realism. The former is consistent with most of the discourse on (de-)globalization in the press and among IB 
Table 1 Key characteristics of liberalism and realism as related to (de-)globalization

\begin{tabular}{|c|c|c|}
\hline & Liberalism & Realism \\
\hline Actors & $\begin{array}{l}\text { Anyone, including individuals, firms, NGOs, } \\
\text { states, international organizations }\end{array}$ & Sovereign nation states, especially powerful ones \\
\hline Interests & $\begin{array}{l}\text { Self-interest broadly conceived, such as } \\
\text { economic considerations, personal and } \\
\text { cultural values, etc. }\end{array}$ & Survival of the nation state \\
\hline Power & $\begin{array}{l}\text { Any kind, including } \\
\text { Hard power (coercion though military and } \\
\text { economic strength) } \\
\text { Sharp power (distraction and manipulation) } \\
\text { Soft power (co-optation through attraction) }\end{array}$ & Hard power \\
\hline Assumptions about rationality & Rational on average & Rational \\
\hline Role of domestic politics & $\begin{array}{l}\text { Crucial as countries' foreign policies reflect } \\
\text { domestic political configurations }\end{array}$ & Irrelevant \\
\hline $\begin{array}{l}\text { Nature of international } \\
\text { interaction }\end{array}$ & Zero-sum or positive-sum & Zero-sum \\
\hline Role of international institutions & Crucial for positive-sum outcomes & Irrelevant: epiphenomenal to power \\
\hline Foundation of globalization & $\begin{array}{l}\text { Agreement of states to increase } \\
\text { interdependence } \\
\text { Institutional infrastructure to facilitate } \\
\text { cooperation }\end{array}$ & Coercion of states by a global hegemon \\
\hline Triggers of de-globalization & $\begin{array}{l}\text { Changing interests leading to states' opting out } \\
\text { of their prior agreements } \\
\text { Ineffective institutions out of synch with states' } \\
\text { interests }\end{array}$ & $\begin{array}{l}\text { Hegemonic decline leading to loss of sufficient } \\
\text { coercive power }\end{array}$ \\
\hline $\begin{array}{l}\text { Likely shape of international } \\
\text { economic relations under de- } \\
\text { globalization }\end{array}$ & Patchwork: coalitions of the willing & $\begin{array}{l}\text { Emergence of a new global hegemon: new } \\
\text { globalization according to the interests of the } \\
\text { new hegemon } \\
\text { Multiple regional hegemons: multiple regimes } \\
\text { structured around these hegemons } \\
\text { No hegemon: disorder }\end{array}$ \\
\hline
\end{tabular}

scholars, while the latter represents the dominant school of thought in International Relations.

The term "liberalism" has come to mean different things to different people and thus represents a source of potential confusion. In this paper, "liberalism" and any of its derivatives will exclusively denote the International Relations theory by this name as introduced below. It will never imply outcomes such as an open economy, nor will it refer to a political philosophy of individual freedom and rights or an ideology concerning social welfare policies.

Both liberalism and realism have evolved multiple variants. For the purpose of this discussion, I focus on the theoretical formulations growing out of the two foundational pieces of modern International Relations theory, Moravcsik's (1997) conceptualization of liberalism and Waltz's (1979) structural realism. For an overview of other variants, I refer the reader to International Relations primers (e.g., Matthews \& Callaway, 2017) or any major International Relations textbook (e.g., Pevehouse \& Goldstein, 2016).

Table 1 presents an overview of the main characteristics of both approaches, their conceptualizations of (de-)globalization, and their predictions about the future landscape of international 
economic activity. In the following paragraphs, I first lay out the main concepts and mechanisms envisioned by these theories before turning to the questions of how they relate to (de-)globalization and the kind of future each approach predicts.

\section{General Mechanisms}

\section{Liberalism}

Liberalism permits a wide range of actors, interests, and forms of power to determine political outcomes. While countries ${ }^{4}$ represent the major actors in international politics, possible actors codetermining outcomes further range from the individual to the international, including individuals, firms, non-government organizations (NGOs), and international organizations such as the European Union (EU), the World Trade Organization (WTO) or the United Nations. Liberalism assumes these actors to be rational on average, that is, deviations from rationality are possible.

By engaging in politics, these actors pursue their self-interests, a term that is very broadly conceived. It includes questions of economic welfare, but also permits other preferences including those based on personal and cultural values. Depending on the interests at hand, actors may seek to attain their objectives through positive-sum cooperation (e.g., economic wealth through trade) or zero-sum competition (e.g., national security through military strength).

In pursuing their respective interests, actors have recourse to a wide range of different forms of power. These include hard power, which usually rests on coercive capabilities such as military strength or the ability to inflict economic damage (Nye, 1990); sharp power (Walker \& Ludwig, 2017), which draws on distraction and manipulation to weaken opponents and shore up one's own position; and soft power (Nye, 1990), which relies on co-optation of others by presenting an attractive model or outcome.

In the resulting dynamics, what happens domestically - i.e., inside countries - is at least as important as what happens between countries. Countries may be the major actors in international politics, but, in liberalism, their interests are a reflection of domestic interests, with more powerful actors having greater influence on foreign policy. Depending on the issue area and the structure of the respective country, foreign policy may reflect the interests of different constituents: for instance, those of a few powerful actors in authoritarian dictatorships, those of special interests in countries with strong business lobbies, those of a plurality of the people in countries with first-past-the-poll elections, or of a societal consensus in Northern European corporatist societies. As actors and their interests shift, so does the focus and thrust of foreign policy.

Liberalism thus presents a fairly accurate depiction of reality, with all its complexity. This is also its major weakness as a theory. It is so permissive in terms of the possible actors, their respective interests and the various forms of power that may matter that it can be very difficult to arrive at a conclusive analysis and prediction for specific issues.

\section{Realism}

The realist school narrows down this wide range of possible actors, interests, and forms of power considerably. Actors are sovereign countries, especially great powers. Countries are unitary, rational actors, with domestic politics being irrelevant for their behavior in the international system. This is because under the additional assumption of anarchy in the international system - the notion that there are ultimately no rules constraining state behavior as there is no overarching authority that could enforce compliance - securing survival becomes the primary concern of states. The main objective of foreign policy is thus forced on countries by the structure of the international system, and countries permitting themselves to get distracted from the objective of survival by domesticlevel political concerns risk their survival.

In the anarchic world of realism, securing survival is ultimately a function of hard power. In particular, countries need to acquire sufficient military power to defend themselves against other countries. Since building and maintaining armies requires resources, this implies an attendant need for economic strength. With power representing primarily a tool for securing survival against other countries, the emphasis is on relative rather than absolute power. Economic growth of $10 \%$ per year may enable a country to increase its power considerably in absolute terms, but from a realist perspective it is still falling behind if at the same time another state grows by $20 \%$. Relations between countries thus become a zero-sum game.

Realism presents a much tighter theoretical approach than liberalism. Ironically given its name, realism offers a very reductionist rather than realistic picture of international politics. As a 
consequence, a salient point of criticism is that it may miss important parts of the picture. For instance, in a strict application of realism, the EU is not a relevant actor, as it does not represent a sovereign nation state. Not everyone finds the fallback position of realists - that the $\mathrm{EU}$ is ultimately the expression of the power of one member state (or possibly several of them) convincing, considering the extent of horse-trading in which even the most powerful EU members must engage to attain their objectives.

\section{Relationship with (De-)Globalization}

\section{Liberalism}

For liberalists, globalization involves two major ingredients: the agreement of states to cooperate in building interdependence, and a supporting infrastructure that enables such cooperation to occur.

The first component, agreement, requires that there be sufficient political support for building economic interdependence within each country. In other words, proponents of openness need to have more political power than opponents.

While such agreement is an expression of the will to cooperate, putting cooperation into practice often faces challenges because of a risk that other countries will renege on their agreements in order to gain even greater benefits for themselves. Liberalists usually conceptualize this challenge in gametheoretic terms (e.g., Aggarwal \& Dupont, 1999; Maggi, 1999), especially with reference to the prisoners' dilemma: while overall benefits of cooperation may be maximized if everyone cooperates, individual players may maximize their own benefits by defecting while the others continue to cooperate. Since this incentive structure is known, the risk is that no actor agrees to cooperate.

Liberalists claim that countries can overcome the constraints of anarchy and build cooperation in at least three ways. First, because actors, especially states, interact with one another repeatedly, the gains from a one-time defection pale in comparison with the possible gains from long-term cooperation. Since countries realize who can be trusted and who tends to cheat, defecting does not pay. Rational actors will thus learn to cooperate (Axelrod, 1984). Second, cooperation can be helped along through the use of strategies that reward cooperation and punish defection. For instance, adopting a simple "tit-for-tat" approach - doing whatever the partner did last - tends to lead to stable cooperation over time (Axelrod, 1984).

Third, and most important for the understanding of de-globalization, is the argument that just as institutions facilitate cooperation within countries (North, 1990; Williamson, 1985), international institutions (also called "international regimes") may enable international cooperation (Keohane, 1984, 1989). Institutions in this context are defined as "persistent and connected sets of rules (formal and informal) that prescribe behavioral roles, constrain activity, and share expectations" (Keohane, 1989: 3). This conceptualization is broadly consistent with that by North (1990), commonly used in the international business literature. (Somewhat confusingly, the bodies entrusted with administering international institutions, such as the WTO, are also referred to as "institutions," while the business literature would see them as "organizations" (defined as groups of people bound together for a common purpose; see North, 1990)).

Liberalists argue that institutions aid cooperation in a number of ways (Davis, 2012; Maggi, 1999; Matthews \& Callaway, 2017). They provide a forum for discussion, for identifying mutual interests, and for finding joint solutions. Once institutions are agreed on, the organizations attached to them can help monitor compliance. Some of these organizations also provide for adjudication of conflicts around international institutions and set penalties for violations. Liberalists would not deny that compliance with international institutions is imperfect but would argue that imperfect institutions are better than none, with successful cooperation having the potential to open up further areas of cooperation in the future.

In a liberalist world, there are accordingly two pathways to de-globalization. The first is for the institutional infrastructure supporting globalization to lose its ability to support openness. For instance, diverging interests between countries may prevent the creation or maintenance of the institutions necessary for openness to sustain or advance. We have seen such a divergence of interests in the context of the Doha Round of WTO negotiations, in which advanced industrialized countries essentially pushed for more free trade (except in agriculture), while the emerging markets pushed for what they saw as fair trade. Unlike in previous rounds, in which the advanced 
industrialized countries were powerful enough to push through their interests, increased power of emerging markets resulted in a stalemate in the Doha Round.

Such stalemate and attendant lack of institutional changes does not only work against the opening up of new areas of economic interdependence. It also contributes to institutional drift (Mahoney \& Thelen, 2009), which implies that institutions move out of synch with the issues they should address. For instance, countries have shown great ingenuity in devising ways to renege on their promise of openness while officially remaining in compliance. An example is non-tariff barriers to trade, which many states have thrown up and which the WTO remains ill-equipped to address. Such circumvention of international institutions both reduces interdependence directly - by making trade with and investment in other countries harder - and indirectly - by inducing other countries to reciprocate by limiting openness.

This reneging is linked to the second pathway: a change in national political interests leads countries to opt out of economic interdependence. Consistent with the notion that shifting interests may be connected with the current de-globalization, public support for globalization has dropped in many economies since the early 2000s (OECD, 2017). In a November 2016 survey across 23 advanced and emerging markets, an average of $53 \%$ of respondents had little or no confidence in international institutions, $61 \%$ had little or no confidence in large firms, and a large minority was concerned about immigration (with no majority in favor) (IPSOS, 2017).

As to the causes of this shift, given the flexibility of liberalism with respect to interests, a wide range of causes is conceivable. For example, values underlying policy preferences may undergo ideological shifts away from open to protected markets. Since ideologies legitimate positions of power (Mannheim, 1936), such shifts usually require a failure, perceived or real, of the prevailing ideology. Arguably, the financial crisis of 2008 and the European refugee crisis of 2015 represented such watersheds against pro-openness ideology in the Western world. The former empowered left-wing critics of globalization, who object to openness in its present shape, which they see as unjust (Fisher \& Ponniah, 2003; Santos, 2013; Verbeke et al., 2018). In particular, leftist activists object to an investment- and corporation-led form of globalization in which investors and firms are seen as benefiting at the expense of common people, some countries, and the environment. The latter reinforced support of right-wing nationalist groups linking globalization to unwelcome immigration (Rodrik, 2018), which seems to have played a role in the Brexit vote of 2016. Jointly, the rise of such opposition and attendant challenges to pro-market ideology are likely to weaken support of openness at the domestic level, with concomitant implications for a country's ability to pursue international economic interdependence.

Second, opening up trade or finance internationally has distributional consequences within countries, with some sectors gaining and others losing. For instance, international trade or financial liberalization will generally hurt previously protected sectors and their workers (Buckley \& Ghauri, 2004; Frieden, 1991; Stolper \& Samuelson, 1941). Lowskilled workers suffer in terms of wage depression and job losses - and resultant increases in inequality - when exposed to competition from emerging markets, as has been shown for US workers facing competition from China (e.g., Acemoglu, Autor, Dorn, Hanson, \& Price, 2016; Autor, Dorn, \& Hanson, 2013). Unless compensated, the losers from globalization may mobilize and seek to reverse economic openness (Autor, Dorn, Hanson, \& Majlesi, 2016; Frieden, 1991). If these actors then have sufficient power - for instance, by being numerous enough to elect a leader aligned with their interests a country may shift its foreign economic policy in favor of de-globalization. Arguably, this accounts at least partially for the election of Donald Trump as U.S. President and the global rise of populism more generally (Rodrik, 2018).

A third example is that the payoffs from cooperation may change over time, and interests supporting globalization may weaken as a consequence. For instance, while importing goods or offshoring production may be economically efficient in the short term, the attendant shrinkage of production in the home market may be undesirable in the longer term for reasons such as a reduction in expertise and production capacity in industries important for national defense (Berger, 2013). We have also observed this mechanism in recent years, for example, in the context of growing numbers of Chinese foreign direct investment projects blocked in Western nations on grounds of national security. 
Overall, the picture drawn by liberalism is consistent with de-globalization. International institutions appear to be weakening, and domestic political interests seem to have shifted to favor reduced interdependence.

\section{Realism}

For realists, the main pathway to globalization involves coercion. This is the thrust of a sub-theory of realism called "hegemonic stability theory" (Keohane, 1980; Kindleberger, 1973; Krasner, 1976). Hegemonic stability theory argues that periods of globalization occur when an overwhelmingly powerful country, a "hegemon," creates and maintains, for its own benefit, sets of international institutions ("regimes") that govern aspects such as trade and investments. The hegemon will keep this system in place as long as it remains strong enough to do so and the benefits from keeping the system exceed the costs. Other states may or may not benefit from the system.

Once the hegemon declines - i.e., it loses power relative to other countries to the point that it is no longer overwhelmingly powerful - the system becomes unstable. While hegemonic decline has been a persistent pattern in history (Gilpin, 1983; Organski, 1958), it is not necessarily clear precisely when a state ceases to be a hegemon. As a result, an economic order may outlive the hegemony of the country that created it - it is "sticky" (Krasner, 1976). It will fail once a shock to the system, such as an economic crisis, reveals that the hegemon has lost its power to maintain that system.

Importantly, while the international system under hegemonic stability may look much like an institutional structure along the lines of that envisioned by liberalism, these institutions are in reality epiphenomenal: they do not exist in their own right but reflect the interests and power of the hegemon. In essence, they are a matter of convenience for the hegemon: it is easier to hand out a rule book than to tell each country on a case-bycase basis what to do.

The theoretical parsimony of realism makes it much more straightforward to illustrate how the current period of de-globalization coincides with hegemonic decline. Hegemonic stability theory links the openness of the international economic system to the preponderance of the most powerful country, which in recent history has been the United States of America. Conversely, de-globalization accompanies a decline in power of the strongest state, not necessarily in absolute terms, but relative to other states. If such decline is present, one would expect de-globalization.

To assess this possibility, I evaluate the relative power of the United States as compared with the rest of the world and its closest rivals. I focus on two main dimensions that are central to the realist concept of power: military strength and economic power. The latter is easy to operationalize as GDP. Military power, on the other hand, is difficult to measure without a detailed, and probably classified, understanding of the capabilities of the world's militaries, including the number and capabilities of soldiers and equipment. As a proxy, I rely instead on the extent of military spending. This measure is imperfect in that it does not account for classified budgets; does not differentiate between spending for new equipment as opposed to ongoing operations; and does not account for purchasing power differences. At the same time, the resultant biases all work against finding a decline in power in the current context: budget transparency is greater in the US than in its next closest military rivals, China and Russia; the US has been spending much more on ongoing wars in the past 15 years than any other nation, with concomitant expenses for veterans; and much of the world, but certainly China and Russia, should see greater purchasing power per dollar spent on the military than the United States. Any decline in the US budget relative to other states is thus likely to be a conservative depiction of actual dynamics.

Both metrics paint a clear picture of relative decline of US power. Figure 8 shows US GDP at PPP and constant 2011 international dollars relative to all other countries in the world combined, as well as relative to the respective next largest economy in the world (Japan until 1998, China from 1999 onward). The time series begins in 1990 because the World Development Indicators database used does not report GDP at PPP for earlier years. Relative to the rest of the world, US economic strength in this period peaked in 1999 at 20.6\%. By 2017, that figure had declined to $15.2 \%$ of world GDP, a drop of $26.2 \%$. The picture is even clearer for US GDP relative to the next largest. Again, US strength peaked in 1999 with its GDP at 289.4\% that of China's. By 2013, China had reached parity, and in 2017, US GDP was down to $83.2 \%$ of China's, a decline by $71.3 \%$. While one can argue whether the United States was an economic hegemon in 1999, it is clear that, by 2017, it was far from hegemony. At the same time, it is also clear that China is not (yet?) an economic hegemon, either. 


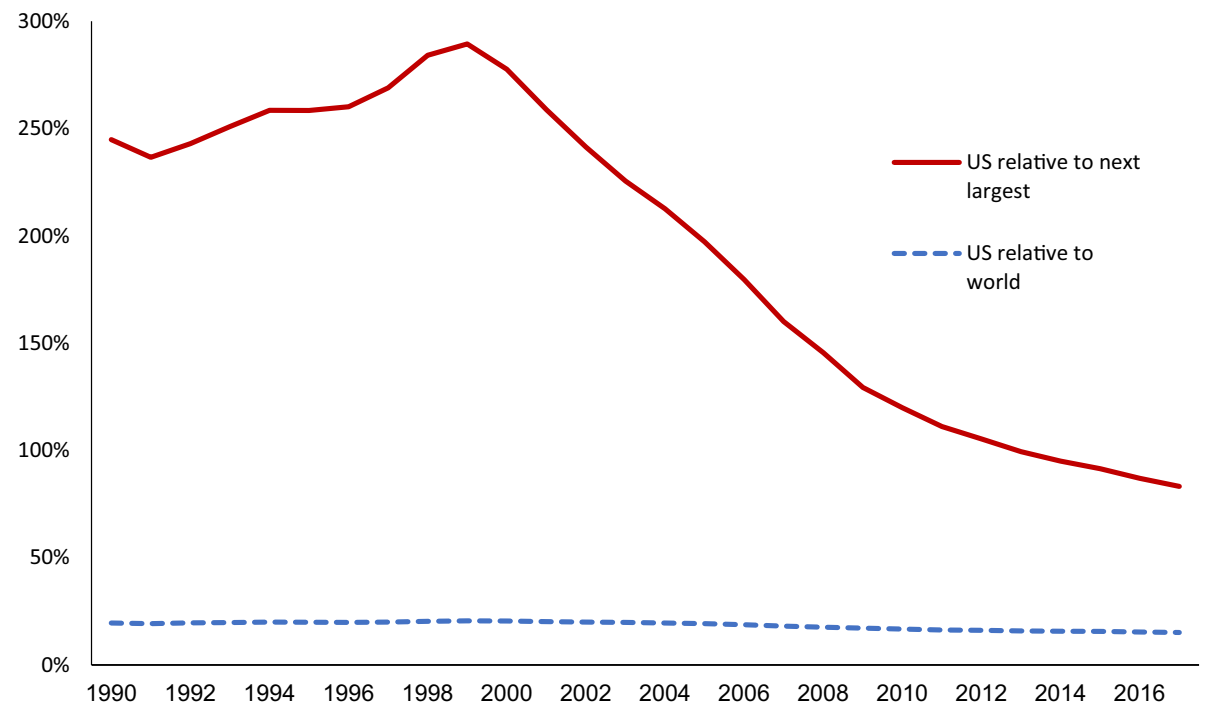

Figure 8 US GDP at purchasing power parity and in constant 2011 international dollars relative to the next largest economy and the world. For a table with the values, please refer to the Appendix. Source: World Bank (2018).

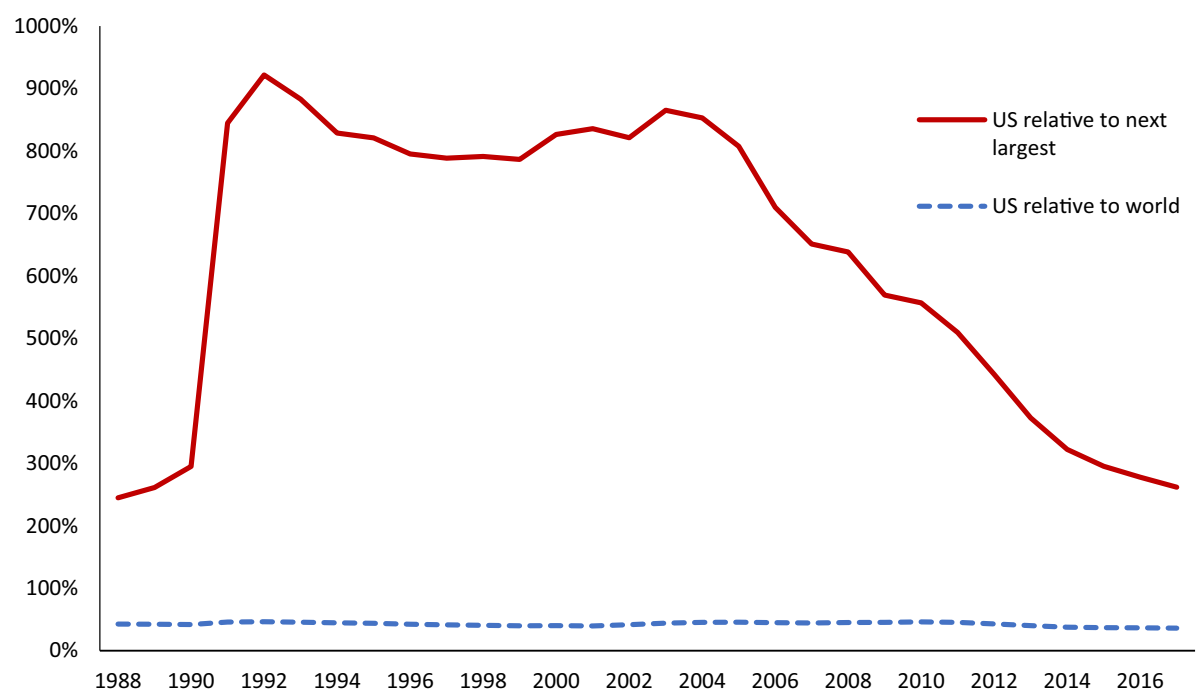

Figure 9 US military spending relative to the next largest spender and the world. For a table with the values, please refer to the Appendix. Source: Stockholm International Peace Research Institute (2018).

Figure 9 shows US military spending relative to all other countries in the world combined, as well as relative to the respective next largest spender (USSR 1988-1990, France 1991-2000, China 2001 onward). It is measured in constant 2016 international dollars, with PPP adjusted data unavailable. The time series begins in 1988 because this is the earliest year for which the SIPRI database (Stockholm International Peace Research Institute, 2018) contains a budget for the Soviet Union, which during the Cold War was the closest military contender to the United States. Military spending followed a similar pattern to GDP, though peaking earlier. Relative to the rest of the world, US military spending reached its high point in 1992 at $46.4 \%$. By 2017, it had declined to $36.1 \%$, a drop by $22.2 \%$. Again, the picture is even clearer relative to the next closest contender: US spending peaked in 1992 at $921.7 \%$ that of the next closest, France. By 2017 , it had decreased to $261.7 \%$ relative to the Chinese military budget, a drop of $71.6 \%$. As already mentioned, especially the more recent figures are likely to underestimate the attendant shift in military power. 
Overall, these data show a picture that is consistent with de-globalization. To the extent that the United States used to be a hegemon that could erect and maintain an open international economic system, it is unlikely that it remains powerful enough today. Its economy is already smaller than China's, and the Chinese military is rapidly catching up.

\section{Outcomes}

Both approaches would thus expect de-globalization under the present conditions. However, their predictions of the future landscape of the international political economy vary considerably.

\section{Liberalism}

As laid out above, liberalism suggests that deglobalization results from a combination of failing international institutions and interests shifting away from economic openness. To the extent that this change of interests is not uniform across countries - which is probably a realistic assumption - the most likely outcome is a globalization patchwork in which different pairs or groups of countries provide for varying levels of interdependence between them.

Geographically confined agreements are thus likely to gain in importance. The past decades have already seen the emergence of such a globalization patchwork in the shape of numerous bilateral and regional, rather than global, trade agreements (Aggarwal and Urata, 2006; Shadlen, 2008). While these agreements were effectively attempts at increasing interdependence above the global standard, de-globalization implies an additional layer of complexity in that some countries begin to opt out of the system to reduce their levels of interdependence. To the extent such departures threaten the viability of the remaining global infrastructure, countries willing to maintain high levels of interdependence may find a need to devise suitable bilateral and regional agreements. Similar to past agreements, these alternative arrangements are likely to be tailored to the interests of the countries negotiating them. Given diverse interests, it seems likely that variance in the extent and characteristics of economic openness will increase.

In the extreme, this may result in the reemergence of economic blocs seen in the 1930s, with currency and trade restrictions in place (Jones, $2005,2014)$. While these restrictions between blocs curtailed overall FDI, some countries still registered growing FDI from other blocs, as profits from existing operations could not be repatriated and were instead reinvested (Jones, 2005). The attendant rise in local assets and production may have helped MNEs mitigate the impact of trade barriers. Unfortunately, it also implied larger losses during World War II, when the combatants confiscated enemy assets (Jones, 2005; Jones \& Lubinski, 2012).

\section{Realism}

Realism essentially predicts globalization in the presence of a global hegemon. In a multipolar world, in which at least two superpowers represent regional (in the sense of not global) hegemons and neither is strong enough to become a global hegemon, realism would expect the emergence of economic blocs around each regional hegemon, supported by different sets of institutions (regimes).

The most likely outcome under realism for the near to medium future is thus a repeat of the Cold War configuration of the international political economy: a bipolar world in which two superpowers erect two different systems in their respective spheres of interest. In this context, the United States remains less than a global hegemon, but strong enough to deny China the mantle of global hegemony. This may be a transitional phase for the next decades, or it may become a permanent condition if China fails to break through the middle income trap and thus does not grow much stronger (Lewin, Kenney, \& Murmann, 2016; Witt, 2016).

In the longer run - presumably some decades hence - the world may see the emergence of China as a new global hegemon. For this case, hegemonic stability theory would suggest the creation of a new global order reflecting Chinese preferences. The smoothest transition would be for the United States to concede international leadership voluntarily to China. This seems unlikely. For a realist, it is more probable that leadership will be wrested from the United States. Possibly, this may occur in the context of a hegemonic war (Allison, 2017; Gilpin, 1983), but, given the threat of nuclear annihilation, conflict may be confined to economic or perhaps digital warfare.

How China would then refashion the international system is difficult to predict beyond such obvious changes as the Chinese yuan replacing the US dollar as reserve currency and new institutions replacing existing ones. Jacques (2012), for instance, extrapolated from history to suggest the emergence of a neo-tributary structure in which 
Chinese views of different races play an important role. Whether this is a credible prediction and specifically what this would entail remains unclear.

However, the longer run might also see the emergence of other superpowers and thus a multipolar world with multiple economic regimes. Since population size and thus the attainable total size of GDP is a key indicator of power in realism, the most likely candidate to attain superpower status in the future is India. This is contingent on continued economic development of the country, which is not a foregone conclusion given past economic performance and the possibility that especially China may seek to prevent the emergence of India as a competitor.

An unlikely candidate for superpower status is the European Union. The early 2000s saw a series of aspirational works that suggested that the EU might indeed be a coming superpower (Leonard, 2005; McCormick, 2007; Verhofstadt, 2006). The euro crisis put an end to such hopes, at least for now (Webber, 2016). In particular, the past 10 years have revealed that even though the EU would in principle have a sufficiently large economy and population, it lacks the "power conversion capability" requisite for superpower status (Nye, 2015: 25). The problem is that EU norms of near-consensual decision-making paired with the frequently diverging interests of member states drastically reduce the ability of the EU to act (Webber, 2016). Unless this changes as a result of further integration, presumably into a United States of Europe, superpower status is likely to remain beyond reach.

Other countries are generally too small to become poles in a multipolar world. This includes Russia. Given its relatively small population of 144 million, it could not match the power of any of the other superpowers even if it managed to attain per capita GDP levels as in the advanced industrialized world. By the same token, Japan with a shrinking population of currently 127 million will not be able to muster sufficient power.

\section{IMPLICATIONS FOR IB RESEARCH}

The two theories, liberalism and realism, thus predict the emergence of very distinct environments for international business. This has implications for potential exploration and theory development in at least three areas: the political strategies and roles of MNEs, global value chains, and interactions with the national context. I will discuss these in turn below.

\section{Political Strategies and Roles of MNEs}

The above discussion opens up opportunities to explore how MNEs affect the political sustainability of globalization, both in the context of their regular business activities and through deliberate political agency. Liberalism and realism suggest different foci in exploring these questions, with liberalism emphasizing ways to understand and address the negative side effects of globalization and realism pointing to pressure for stronger alignment with the political agendas of states vying for hegemony.

Research in these areas represents an extension of existing thinking about politics in IB. While IB scholars have long been aware of the importance of an international political context that permits globalization (e.g., Buckley \& Casson, 1976), the field has tended to treat this context as exogenous. Accordingly, to the extent that IB research has explored the importance of political strategies, it has tended to do so in the context of strategic outcomes for the individual firm, such as entry and location choices, entry modes, ownership patterns, legitimacy, risk reduction, and performance (Cui, $\mathrm{Hu}, \mathrm{Li}, \&$ Meyer, 2018; Sun, 2019). Absent, with some exceptions already noted (Kobrin, 2017; Meyer, 2017), is a concern with the relationship between MNEs and the political context that enables and sustains globalization.

The discussion in this paper suggests that the international political context underpinning globalization is in fact endogenous to IB. For one, both liberalism and realism agree that the trade and investment decisions of MNEs feed back into the political context, though in distinct ways. In liberalism, as discussed earlier, MNEs affect domestic interests in part through the distributional consequences of their trade and investment decisions, with disadvantaged parts of the population opposing openness. As also discussed, MNE activities further clash with competing ideologies on the left and the right of the political spectrum, and the more successful and thus salient MNEs become, the stronger is an anti-globalization response likely to be.

In realism, MNEs' activities across boundaries have the potential to affect the distribution of power among states. For instance, MNEs may slow the economic development of potential rivals by using their international market presence to block the emergence of rival firms (see Hymer, 1976). Asian developmental states of the twentieth century, such as Japan and South Korea, consequently 
sought to curtail inward FDI (Amsden, 1989; Johnson, 1982). On the other hand, MNEs may also help rival countries gain economic strength. For instance, MNE investments abroad increase host country GDP, and MNE activities abroad may lead to technological spillovers (e.g., Buckley, Clegg, \& Wang, 2002; Giroud, 2014; Meyer \& Sinani, 2009; Ramamurti, 2004) that can strengthen rivals. This in turn would presumably induce a hegemon to adjust the international regime it created so as to ensure continued relative gains in its favor.

The result in both cases is a coevolutionary dynamic (Lewin \& Volberda, 1999) of globalization and MNE activities that, through different mechanisms, may be self-destabilizing and lead to deglobalization.

For IB research, with MNE activities as one central theme, liberalism and realism thus open up large, but different, questions about the relationship between MNEs and the political context that enables them. With respect to regular business activities of MNEs and their outcomes, liberalism implies a need to place a greater premium on sustaining societal support for globalization. For instance, as already mentioned, we know that the investment and trade activities of MNEs produce winners and losers within a given national context. A liberalist would expect MNEs to give these mechanisms greater weight in future decisionmaking than they have so far. While there are national differences - discussed in a later section this would broadly be evident in a shift away from a shareholder focus towards a more encompassing stakeholder view of the firm (Agle, Donaldson, Freeman, Jensen, Mitchell, \& Wood, 2008; Freeman, Wicks, \& Parmar, 2004).

Realism suggests the importance of generating a better understanding of how MNE activities support or undermine hegemony. In a direct sense, this includes the possibility that home country governments will determine at least part of MNE activities - in other words, that MNEs represent political tools for attaining power. For instance, the literature on Chinese MNEs has noted that a key objective of Chinese outwards FDI has been to secure access to resources abroad (e.g., Buckley, Clegg, Cross, Liu, Voss, \& Zheng, 2007; Child \& Rodrigues, 2005; Cuervo-Cazurra, 2017; Luo \& Tung, 2007), a critical concern from a realist perspective. Similarly, the springboard perspective (Luo \& Tung, 2007, 2018) of leveraging foreign investments to upgrade internal capabilities by acquiring them abroad (Child \& Rodrigues, 2005;
Deng, 2009) can be interpreted as efforts in support of accelerated growth of Chinese power. The involvement of Chinese MNEs in the One Belt One Road initiative (also known as Belt and Road Initiative), which is as much a geopolitical as an economic project (Ferdinand, 2016), may be a current, large-scale example of Chinese MNEs serving state interests. Of course, China is not unique in this respect. For instance, the activities of US MNEs can, and have been, viewed as projections of US hegemony (Gilpin, 1975; Kindleberger, 1969).

A second set of questions relates to political agency of MNEs. It is well-established in the management and IB literature that firms engage in political processes to help shape their environment (e.g., Boddewyn \& Brewer, 1994; Oliver, 1991; Pfeffer \& Salancik, 1978; Witt \& Lewin, 2007). We also know that firms can and do use tailored nonmarket strategies, such as corporate social responsibility (CSR) and systematic engagement of local stakeholders, to create hospitable environments for their operations in host markets (e.g., Henisz, 2017; Henisz, Dorobantu, \& Nartey, 2014; Rathert, 2016; Yang \& Rivers, 2009). The question is whether and how we may see MNEs similarly devise and deploy non-market strategies to help shore up the political foundations of the economic openness on which they depend.

Liberalism and realism again suggest very different possibilities. Under liberalism, MNEs, especially large ones, may decide to dedicate more resources to sustaining and expanding economic interdependence. This may, for instance, involve an increase in direct political activities, such as lobbying policy-makers to counteract pressure from anti-globalization forces. It could also involve attempts to prevent parts of the population from turning negative on globalization. For instance, MNEs may use CSR activities such as retraining programs to help buffer against the adverse effects of globalization, possibly tailoring these programs to the specific institutional context of home and host countries (Ioannou \& Serafeim, 2012; Jackson \& Apostolakou, 2010; Matten \& Moon, 2008; Miska, Witt, \& Stahl, 2016; Rathert, 2016). Many major firms already pursue both political strategies and CSR, and it would be surprising if they did not put them to use to counteract de-globalization, individually or in coalition with other national or international actors.

Realism at first glance seems to rule out that MNE agency could be significant, as domestic politics, and thus the activities of actors such as firms, are 
irrelevant in the theory. If we open the black box of domestic policy-making, however, realism may leave space for MNE agency in the context of normal political involvement in shaping economic policies (see Witt \& Lewin, 2007). To the extent that realism is correct and the survival of globalization depends on the strength of the hegemon, and to the extent firms consider the present form of globalization under the current international regime to be desirable, the question of how policies affect the power of the hegemon would become part of the equation. Especially if the alternative were de-globalization or a less favorable globalized environment under a new hegemon, weaker states and their firms might conclude that it is in their self-interest to permit a hegemon to accrue disproportional benefits.

For instance, in the current international context, European MNEs may consider what impact their economic activities in and with China have on the viability of the US-led international order. In simple terms, realists would argue that anything that strengthens China undermines the ability of the United States to maintain the international economic order it built. European MNEs might also ponder whether it may, in the longer run, be advantageous to give into recent US demands on trade. While the Europeans see these as unbalanced and unfair, they may conclude it to be in their interest to help shore up US power rather than to see continued de-globalization or a Chinese-led form of globalization. In other words, the calculus on what kind of political solutions MNEs choose to support may change.

Taken together, both liberalism and realism open up a wide range of questions related to the political context and agency of MNEs. For instance, how big is the destabilizing impact on globalization of which kinds of MNE activities? Can firms do anything to counteract this impact, or are the forces at work too big even for collective action by the world's largest MNEs? Which kinds of political agency work better and why? And what are appropriate mechanisms for incorporating the destabilizing impact of MNE activity in various aspects of MNE strategy, such as location decisions?

\section{Global Value Chains}

A second area of implications pertains to likely adjustments in global value chains. ${ }^{5}$ While liberalism and realism suggest different pathways, common themes include questions about the future reach and specialization of value chains, possible changes in organizational forms, and the impact of political considerations on location decisions. Below, I use the model of the "Global Factory" (Buckley, 2011; Buckley \& Ghauri, 2004) to illustrate how these issues may play out under the two theories.

In the Global Factory, MNEs essentially become coordinators of production networks in which they "'fine slice' their activities and ... locate each 'stage' of activity in its optimal location and ... control the whole supply chain, even when not owning all of it" (Buckley, 2011: 270). While this view explicitly recognizes the importance of politics in opening up markets (Buckley, 2011), it takes this openness for given. Jointly with technological advances, openness enables the functioning of the Global Factory.

While the technology needed for the Global Factory will probably continue to be available and improve, both approaches discussed in this paper suggest that economic openness is likely to recede. Some of the consequences of this will mirror the gains from internationalization and are independent of the question of which theory better accounts for de-globalization. For instance, in general, benefits from "fine slicing," such as economic or institutional arbitrage (Hall \& Soskice, 2001; Jackson \& Deeg, 2008; Witt \& Lewin, 2007), are likely to decline. Companies will have fewer opportunities to offshore production to countries with lower labor costs or to locate research and development activities in countries with technological strengths in specific areas. Just as globalization opened up these opportunities for MNEs, deglobalization is likely to diminish them and reduce their significance as source of competitive advantage.

The two theories disagree, however, on a range of precise implications for the Global Factory. In liberalism, a breakdown of international institutions would imply more uncertainty in international business, which translates into higher transaction costs of doing business internationally. Transaction costs would presumably also increase with a fragmentation of the international economic order, which would imply an even greater variety of rules and conditions under which MNEs operate. To the extent that the Coasian argument about the nature of the firm (Coase, 1937) is meaningful, this would suggest a return to higher levels of ownership integration in the MNEs of the future. Does this forebode a partial return to the vertically integrated MNE of the past? Or will the mix of more restrictive politics paired with more 
advanced technologies give rise to new organizational forms?

Either way, while under liberalism the MNE of the future may still be global in the sense of being active across the globe, it is likely to have smaller international reach if some countries opt out of economic openness. The ability of firms to "fine slice" would presumably be curtailed because of a lack of access and scale. Some benefits of specialization may be lost, and some specialized clusters dependent on supplying the Global Factory may decline (see Buckley, 2011).

Location decisions within the remaining available countries would probably become more complex. In addition to the usual parameters determining economic viability and risk as well as the transaction costs of potentially divergent rules of different bilateral and regional agreements, MNEs would need to become more systematic in considering the impact of their projects, both on the host country but especially also on the home country (Meyer, 2017). In this context, certain strategies, such as wholesale factory closures with attendant offshoring of production, will become more difficult to execute and are likely to give way to gentler alternatives, such as stepwise offshoring in which only jobs opened up through natural attrition, such as retirements, may be moved. Such patterns are already relatively more common in coordinated market economies (Hall \& Soskice, 2001) such as Germany (Lewin \& Volberda, 2011), which may consequently be at a relative advantage in terms of internationalization capabilities in a deglobalizing world.

Realism likewise expects smaller reach of MNEs. Unlike under liberalism, however, the Global Factory would probably give way to the Regional Factory (where "region" denotes the economic sphere of interest of the respective regional hegemon). For the probable near-future outcome of two spheres of influence, one led by the United States and one by China, it seems likely that at least the US sphere will continue to operate under rules similar to those today. Under these conditions, the strategy of "fine slicing" remains in principle viable, though on a smaller scale, with reduced levels of specialization and probably not across spheres of influence.

As for the Chinese sphere of influence, as mentioned earlier, it is not clear what the rules of the game for MNEs would be. They may remain fairly similar or deviate dramatically. The larger the differences, the greater the transaction costs of operating across spheres of influence would be (if such cross-sphere activities were condoned by the two hegemons, which in the Cold War they were not). In addition, operating in both spheres implies a risk of asset confiscation in case rivalry turns into open hostility, as happened during both World Wars (Jones, 2005). To handle these tensions, MNEs may try to devise new organizational forms or adapt existing forms, such as compartmentalized business groups (Dieleman \& Boddewyn, 2012). For instance, Beiersdorf, a German firm with Jewish owners, in the 1930s and 1940s sought to reduce the risk of losing assets (ultimately unsuccessfully) to hostile home and host governments by using a "ring" structure to conceal the true ownership of its operations (Jones \& Lubinski, 2012). Where such adaptation is impossible, MNEs currently active in both spheres may find themselves having choose one sphere while withdrawing from the other.

Hegemonic rivalry is further likely to manifest itself as pressure on MNEs to internalize the interests of the respective hegemon in their strategic decision-making, including location choices. Prior work has suggested that the diplomatic networks of home country governments are influential for location decisions (Li, Meyer, Zhang, \& Ding, 2017). It would seem likely that the "home hegemon" might have similar impact. In a direct fashion, a hegemon may put political or regulatory pressure on firms within its sphere of influence, possibly through their own home governments, to avoid or favor certain locations. European firms, for instance, are strongly affected by sanctions the United States imposes on third countries. But even in the absence of direct pressure, the relationship between regional hegemons is likely to color the diplomatic ties between governments, which might affect the viability of international location options.

\section{Interaction with National Contexts}

The third set of implications from this paper involves a wide-ranging research agenda for comparative institutional and contextual research in IB. Liberalism suggests a concern with the ability of national contexts to sustain globalization, while realism asks how national contexts tie into economic and military power.

As discussed earlier, liberalism predicts a patchwork of openness in a de-globalizing world. For MNEs, this implies uncertainty over which economies will remain open. One possible factor in this may be national variance in the extent to which 
MNEs adopt strategies that undermine political support of globalization. For instance, we know from the variety of capitalism literature (EstevezAbe, Iversen, \& Soskice, 2001; Hall \& Soskice, 2001) that advanced industrialized countries vary widely with respect to employment protection. As a result, globalization seems to affect workers more adversely in liberal market economies such as the United States, where low protection makes wholesale factory closures possible and thus facilitates large-scale offshoring. While such offshoring may result in lower consumer prices at the level of the economy as a whole (Feenstra et al., 2010), at the individual level of the affected worker, the overall impact seems to be adverse (Acemoglu et al., 2016; Autor et al., 2013). Conversely, in coordinated market economies (CMEs) such as Germany, employment protection is much stronger, which makes factory closures and large-scale offshoring harder (Lewin \& Volberda, 2011; Milberg \& Winkler, 2010). CMEs may forgo macroeconomic gains from offshoring, such as lower prices and resultant consumption, but higher levels of job security and a higher labor share of income in the economy (Milberg \& Winkler, 2010) may dampen anti-globalization sentiment.

Much about these linkages between national context and MNE strategies affecting support for globalization remains conjecture and thus fruitful grounds for exploration. For instance, beyond employment protection, what other types of institutions may play a role in these processes? Plausible candidates include tariff and non-tariff barriers to trade and investment, but there may be others, such as a reliance of firms on specific, nationally embedded production processes that are hard to transfer to other institutional contexts (Zimmermann \& Bollbach, 2015). Recent research on institutional patterns among the world's major economies may provide a useful empirical basis for exploring these questions (Witt, Kabbach de Castro, Amaeshi, Mahroum, Bohle, \& Saez, 2018).

A second and related aspect is the ability of national institutional contexts to provide a buffer against the adverse impact of globalization by embedding market forces (see Polanyi, 1944; Ruggie, 1982). What combinations of measures, such as unemployment protection and (re-)training schemes, produce sufficient political support of openness? The variety of capitalism literature has shown that multiple institutional configurations can produce similar economic outcomes (Hall \& Soskice, 2001; Judge, Fainshmidt, \& Brown III,
2014; Witt \& Jackson, 2016). In the same spirit of equifinality, it may be possible that multiple ways of embedding the adverse impact of globalization may be feasible (e.g., Milberg \& Winkler, 2010). Probing these variations will give IB an opportunity to extend insights from the welfare state literature (Castles, Leibfried, Lewis, Obinger, \& Pierson, 2012) to explore the interplay of trade, MNEs, and welfare policies.

Realism raises the issue of how institutions and other factors, both at home and abroad, can be leveraged to maximize economic and military power. Prior IB research has linked institutional variations to economic performance (Judge et al., 2014), patterns of innovation (Schneider, SchulzeBentrop, \& Paunescu, 2010), and the ability to take advantage of innovation (Witt \& Jackson, 2016). Similarly, IB research has a long tradition of looking at questions of national competitiveness, for instance, in the context of the double diamond model (e.g., Cho, Moon, \& Kim, 2009; Moon, Rugman, \& Verbeke, 1998; Rugman \& D'Cruz, 1993).

At the same time, much remains to be explored about the linkages between context and hard power. It seems likely that these connections exist. For instance, in the US, Cold War defense spending funded the rise of Silicon Valley and other hightech clusters in the United States (Lécuyer, 2006; O'Mara, 2015). Among the fruits of these efforts are the Internet, which grew out of a defense initiative for distributed computing (Castells, 2002), as well as the US microelectronics and aviation industries (Hooks, 1990). In all of these areas, US MNEs continue to be major global players. In effect, US defense spending assumed the role of industrial policy in other countries (Amsden, 1989; Gerschenkron, 1962; Johnson, 1982; Wade, 1990).

An important question for the future is how the institutional structures of countries, especially those of the United States and China, will help or hinder their efforts at maximizing power. For instance, the institutional structure of the US economy has co-evolved to support a large population of experiments, in the form of startups, that drives high-tech innovation in many parts of the economy (Hall \& Soskice, 2001; Witt \& Lewin, 2007). Leading universities attracting top global talent as well as opportunities to generate vast personal wealth are integral parts of this model. China's approach has been different. While US technology incumbents regularly absorb startups, acquisitions by China's three giants - Alibaba, 
Baidu, and Tencent - seem to reduce the number of independent startups and thus of experiments at a much larger scale (Economist, 2018). Chinese universities have improved markedly, but, rather than seeking to attract leading global talent, the emphasis seems to be on enticing Chinese nationals educated abroad to return to China.

How will these and other differences hinder or help either country gain technology leadership in crucial areas such as artificial intelligence? For instance, will the United States continue to be able to keep, rather than merely to train, top talent from China, which presently accounts for one-third of international students in the United States (Institute of International Education, 2018)? How about other areas of variation in their institutional structures, such as sources and costs of corporate funding (market-driven in the United States, statedetermined for targeted firms in China) (see Hall \& Soskice, 2001; Redding \& Witt, 2007; Witt \& Redding, 2014)? How about aspects such as data protection (weak in the United States but even weaker in China)? Given the central role realism ascribes to hard power for the future of (de-)globalization, elucidating these linkages and their local contingencies could be a promising avenue for future IB research.

\section{CONCLUSION}

The central argument of this perspective paper has been that international business under de-globalization would look qualitatively different from what we have seen in the past decades, and that coming to terms with this qualitative shift would require a much deeper integration of political forces in IB research. Just as in the last de-globalization in first half of the twentieth century, there is no lack of technology that could propel globalization forward. What we do seem to lack, at this point, is a political configuration that would support this.

To help IB research attain this deeper integration of politics, I have reviewed the key tenets of the two leading political science theories speaking to deglobalization, liberalism and realism. While the leading theory of international relations in political science is the latter, most discourse in the media and among IB scholars has been consistent with the former. These theories spell out different mechanisms for (de-)globalization, and they predict different outcomes of de-globalization processes, with attendant implications for the shape of the political economy and thus international business. Based on these differences, I have discussed potential implications for IB research along three dimensions: the political strategies and role of MNEs, global value chains, and interactions with the national context.

The questions this paper has raised are large. Indeed, one might wonder whether many of the questions posed in this paper may not be too large, or too "macro," to be suitable to IB scholars, and whether they may best be left to political scientists.

Of the various possible counters to these concerns, I would like to emphasize two. First, IB has already successfully absorbed a number of macrotopics. For instance, cross-cultural and comparative institutional studies now routinely appear in major IB journals, including JIBS. We have not treated these areas as the exclusive remit of anthropologists, sociologists, and political scientists. The result has been a better understanding of phenomena directly relevant to MNEs, such as the dimensions and impact of liability of foreignness. It seems likely, or at least possible, that widening the view of IB to political factors and mechanisms underlying the shape of the international political economy may produce similar benefits for IB.

Second, studying the interplay of MNEs and the political context constitutes a major opportunity for IB to generate new insights that are as relevant as they are elusive to other disciplines. An oft-heard lament is that IB is a net importer of academic ideas from other disciplines.

Here is an opportunity for generating a positive ideas trade balance with political science. After an initial importation of the theories laid out in this paper, by examining firm-level data, IB scholars may be able to shed light on what has eluded political scientists: a clearer sense of which theory, liberalism or realism, offers a more useful account of actual developments. For instance, as this paper has discussed, the two theories predict different patterns in MNE investments or subsidiary survival under conditions of de-globalization. Since political scientists rarely work with firm-level data, IB scholars will be in a privileged position to identify such patterns. In doing so, IB scholars might also evolve an understanding whether there are contingencies under which one theory is more material than the other. Any meaningful contribution in this area would certainly be another feather in the cap of IB. We should at least reach for it. 


\section{ACKNOWLEDGEMENTS}

I thank Klaus Meyer for his constructive editorial guidance and the three anonymous reviewers for their insightful feedback. I am further grateful for comments and input received from Vinold K. Aggarwal, Christina L. Davis, Geoffrey Jones, Marshall Meyer, Jonathan Story, and Douglas Webber. I also thank for their hospitality the US-Japan Program at Harvard University and the Wharton School, where parts of the work on this paper happened. An earlier version of this paper was presented AIB 2018.

\section{NOTES}

1 "Liberalism" as a term has acquired many meanings; please refer to the text below for clarification what liberalism does and does not mean in the context of this paper.

\section{REFERENCES}

Acemoglu, D., Autor, D., Dorn, D., Hanson, G. H., \& Price, B. 2016. Import competition and the great US employment sag of the 2000s. Journal of Labor Economics, 34(S1): S141-S198.

Adler, E. 1997. Seizing the middle ground: Constructivism in world politics. European Journal of International Relations, 3(3): 319-363.

Aggarwal, V. K., \& Dupont, C. 1999. Goods, games, and institutions. International Political Science Review, 20(4): 393-409.

Aggarwal, V. K., \& Urata, S. (Eds). 2006. Bilateral trade agreements in the Asia-Pacific: Origins, evolution, and implications. London: Routledge.

Agle, B. R., Donaldson, T., Freeman, R. E., Jensen, M. C., Mitchell, R. K., \& Wood, D. J. 2008. Dialogue: Toward superior stakeholder theory. Business Ethics Quarterly, 18(2): 153-190.

Allison, G. 2017. Destined for war: Can America and China escape thucydides's trap?. New York: Houghton Mifflin Harcourt.

Amsden, A. H. 1989. Asia's next giant: South Korea and late industrialization. Oxford: Oxford University Press.

Ashley, R. K. 1984. The poverty of realism. International Organization, 38(2): 225-286.

Autor, D. H., Dorn, D., \& Hanson, G. H. 2013. The China syndrome: Local labor market effects of import competition in the United States. The American Economic Review, 103(6): 2121-2168.

Autor, D., Dorn, D., Hanson, G. H., \& Majlesi, K. 2016. Importing political polarization? The electoral consequences of rising trade exposure, NBER working papers. Cambridge, MA: National Bureau of Economic Research.

Axelrod, R. 1984. The evolution of cooperation. New York: Basic Books.

Berger, S. 2013. Making in America: From innovation to market. Cambridge, MA: MIT Press.

Boddewyn, J. J., \& Brewer, T. L. 1994. International-business political behavior: New theoretical directions. Academy of Management Review, 19(1): 119-143.
${ }^{2} \mathrm{An}$ intriguing possibility is that technology may have reached a point where, unlike in the past, it may increasingly obviate the need for globalization rather than facilitate it. This would reinforce the de-globalizing effect of the regulatory tightening noted in the paper.

${ }^{3}$ Other schools of thought exist, including constructivism (e.g., Adler, 1997; Ashley, 1984; Ruggie, 1983, 1998), Marxist theory in various guises (e.g., Packenham, 1992; Wallerstein, 1980), and feminism (e.g., MacDonald, 2002; Pettman, 2004; Wagner, 2011).

${ }^{4}$ For the purposes of this paper, "states" and "countries" are synonymous.

${ }^{5}$ I retain the customary label "global" in this context. This is without prejudice to the ongoing debate in IB to what extent any firms and their operations have become truly "global," rather than merely international (Verbeke et al., 2018).

Buckley, P. J. 2011. International integration and coordination in the global factory. Management International Review, 51(2): 269.

Buckley, P. J., \& Casson, M. 1976. The future of the multinational enterprise. London: Macmillan.

Buckley, P. J., Clegg, L. J., Cross, A., Liu, X., Voss, H., \& Zheng, P. 2007. The determinants of Chinese outward foreign direct investment. Journal of International Business Studies, 38(4): 488-518.

Buckley, P. J., Clegg, J., \& Wang, C. 2002. The impact of inward FDI on the performance of Chinese manufacturing firms. Journal of International Business Studies, 33(4): 637-655.

Buckley, P. J., \& Ghauri, P. N. 2004. Globalisation, economic geography and the strategy of multinational enterprises. Journal of International Business Studies, 35(2): 81-98.

Castells, M. 2002. The internet galaxy: Reflections on the internet, business, and society. Oxford: Oxford University Press.

Castles, F. G., Leibfried, S., Lewis, J., Obinger, H., \& Pierson, C. 2012. The Oxford handbook of the welfare state. Oxford: Oxford University Press.

Chase-Dunn, C., Kawano, Y., \& Brewer, B. D. 2000. Trade globalization since 1795: Waves of integration in the worldsystem. American Sociological Review, 65(1): 77-95.

Child, J., \& Rodrigues, S. B. 2005. The internationalization of Chinese firms: A case for theoretical extension? Management and Organization Review, 1(3): 381-410.

Cho, D.-S., Moon, H.-C., \& Kim, M.-Y. 2009. Does one size fit all? A dual double diamond approach to country-specific advantages. Asian Business \& Management, 8(1): 83-102.

Coase, R. H. 1937. The nature of the firm. Economica, 4(16): 386-405.

Cuervo-Cazurra, A. (Ed). 2017. State-owned multinationals: Governments in global business. Cham: Palgrave Macmillan.

Cui, L., Hu, H. W., Li, S., \& Meyer, K. E. 2018. Corporate political connections in global strategy. Global Strategy Journal, 8(3): 379-398.

Davis, C. L. 2012. Why adjudicate? Enforcing trade rules in the WTO. Princeton, NJ: Princeton University Press. 
Deng, P. 2009. Why do Chinese firms tend to acquire strategic assets in international expansion? Journal of World Business, 44(1): 74-84.

Dieleman, M., \& Boddewyn, J. J. 2012. Using organization structure to buffer political ties in emerging markets: A case study. Organization Studies, 33(1): 71-95.

Dreher, A. 2006. Does globalization affect growth? Evidence from a new index of globalization. Applied Economics, 38(10): 1091-1110.

Dreher, A., Gaston, N., \& Martens, P. 2008. Measuring globalisation: Gauging its consequences. New York: Springer.

Economist. 2018. Feeding frenzy: Alibaba and tencent have become China's most formidable investors. https://www. economist.com/business/2018/08/02/alibaba-and-tencent-

have-become-chinas-most-formidable-investors. Accessed August 3, 2018.

Estevez-Abe, M., Iversen, T., \& Soskice, D. 2001. Social protection and the formation of skills: $A$ reinterpretation of the welfare state. In P. A. Hall \& D. Soskice (Eds), Varieties of capitalism: The institutional foundations of comparative advantage: 145-183. Oxford: Oxford University Press.

Feenstra, R. C., Lipsey, R. E., Branstetter, L.G., Foley, C. F., Harrigan, J., Jensen, J. B., et al. 2010. Report on the state of available data for the study of international trade and foreign direct investment, NBER working paper series. Cambridge, MA: National Bureau of Economic Research.

Ferdinand, P. 2016. Westward ho - The China dream and 'one belt, one road': Chinese foreign policy under xi jinping. International Affairs, 92(4): 941-957.

Findlay, R., \& O'Rourke, K. H. 2003. Commodity market integration, 1500-2000. In M. D. Bordo, A. M. Taylor, \& J. G. Williamson (Eds), Globalization in historical perspective: 13-64. Chicago: University of Chicago Press.

Fisher, W. F., \& Ponniah, T. 2003. Another world is possible: Popular alternatives to globalization at the World Social Forum. London: Zed Books.

Fraser Institute. 2018. Economic freedom dataset [www document]. https://www.fraserinstitute.org/sites/default/files/efw-2018-masterindex-data-for-researchers.xlsx. Accessed November 4, 2018.

Freeman, R. E., Wicks, A. C., \& Parmar, B. 2004. Stakeholder theory and "the corporate objective revisited". Organization Science, 15(3): 364-369.

Frieden, J. A. 1991. Invested interests: The politics of national economic policies in a world of global finance. International Organization, 45(4): 425-451.

Gerschenkron, A. 1962. Economic backwardness in historical perspective: A book of essays. Cambridge, MA: Belknap.

Gilpin, R. 1975. U.S. Power and the multinational corporation: The political economy of foreign direct investment. New York: Basic.

Gilpin, R. 1983. War and change in world politics. Cambridge: Cambridge University Press.

Giroud, A. 2014. MNEs in Asian business systems. In M. A. Witt \& G. Redding (Eds), The Oxford handbook of Asian business systems: 441-464. Oxford: Oxford University Press.

Guillén, M. F. 2001. Is globalization civilizing, destructive or feeble? A critique of five key debates in the social science literature. Annual Review of Sociology, 27(1): 235-260.

Gygli, S., Haelg, F., \& Sturm, J.-E. 2018. The KOF globalisation index - revisited, KOF working papers. Zurich: ETH.

Hall, P. A., \& Soskice, D. 2001. An introduction to varieties of capitalism. In P. A. Hall \& D. Soskice (Eds), Varieties of capitalism: The institutional foundations of comparative advantage: 1-68. Oxford: Oxford University Press.

Henisz, W. J. 2017. Corporate diplomacy: Building reputations and relationships with external stakeholders. London: Routledge.

Henisz, W. J., Dorobantu, S., \& Nartey, L. J. 2014. Spinning gold: The financial returns to stakeholder engagement. Strategic Management Journal, 35(12): 1727-1748.

Hooks, G. 1990. The rise of the Pentagon and U.S. State building: The defense program as industrial policy. American Journal of Sociology, 96(2): 358-404.
Hymer, S. H. 1976. The international operations of national firms: A study of direct foreign investment. Cambridge, MA: MIT Press.

IMF. 2018a. Balance of payments and international investment position statistics [www document]. http://data.imf.org/. Accessed November 6, 2018.

IMF. 2018b. World economic outlook [www document]. https:// www.imf.org/external/pubs/ft/weo/2018/02/weodata/index. aspx. Accessed November 6, 2018.

Institute of International Education. 2018. Project atlas: United States. https://www.iie.org/Research-and-Insights/Project-Atlas/ Explore-Data/United-States. Accessed November 4, 2018.

Ioannou, I., \& Serafeim, G. 2012. What drives corporate social performance? The role of nation-level institutions. Journal of International Business Studies, 43(9): 834-864.

IPSOS. 2017. Global @dvisor: Power to the people? Part 2. Paris: IPSOS.

Jackson, G., \& Apostolakou, A. 2010. Corporate social responsibility in Western Europe: An institutional mirror or substitute? Journal of Business Ethics, 94(3): 371-394.

Jackson, G., \& Deeg, R. 2008. Comparing capitalisms: Understanding institutional diversity and its implications for international business. Journal of International Business Studies, 39: $540-561$.

Jacques, M. 2012. When China rules the world: The rise of the middle kingdom and the end of the western world (2nd ed.). London: Penguin.

Johnson, C. 1982. MITI and the lapanese miracle: The growth of industrial policy 1925-1975. Stanford, CA: Stanford University Press.

Jones, G. 2005. Multinationals and global capitalism: From the nineteenth to the twenty-first century. Oxford: Oxford University Press.

Jones, G. 2007. Globalization. In G. Jones \& J. Zeitlin (Eds), The Oxford handbook of business history: 141-168. Oxford: Oxford University Press.

Jones, G. 2014. Firms and global capitalism. In L. Neal \& I. G. Williamson (Eds), The Cambridge history of capitalism: The spread of capitalism: From 1848 to the present: 169-200. Cambridge: Cambridge University Press.

Jones, G., \& Lubinski, C. 2012. Managing political risk in global business: Beiersdorf 1914-1990. Enterprise \& Society, 13(1): 85-119.

Judge, W. Q., Fainshmidt, S., \& Brown, J. L., III. 2014. Which model of capitalism best delivers both wealth and equality? Journal of International Business Studies, 45(4): 363-386.

Keohane, R. O. 1980. The theory of hegemonic stability and changes in international economic regimes. In O. R. Holsti, R. Siverson, \& A. George (Eds), Changes in the international system: 1967-1977. Westview: Boulder, CO.

Keohane, R. O. 1984. After hegemony: Cooperation and discord in the world political economy. Princeton, NJ: Princeton University Press.

Keohane, R. O. 1989. International institutions and state power: Essays in international relations theory. Boulder, CO: Westview.

Kindleberger, C. P. 1969. American business abroad. New Haven, CT: Yale University Press.

Kindleberger, C. P. 1973. The world in depression: 1929-1939. Berkeley, CA: University of California Press.

Kobrin, S. J. 2017. Bricks and mortar in a borderless world: Globalization, the backlash, and the multinational enterprise. Global Strategy Journal, 7(2): 159-171.

KOF Swiss Economic Institute. 2018. KOF globalization index 2018 [www document]. https://www.kof.ethz.ch/en/ forecasts-and-indicators/indicators/kof-globalisation-index.html. Accessed November 4, 2018.

Krasner, S. D. 1976. State power and the structure of international trade. World Politics, 28(3): 317-347.

Lécuyer, C. 2006. Making Silicon Valley: Innovation and the growth of high tech, 1930-1970. Cambridge, MA: MIT Press.

Leonard, M. 2005. Why Europe will run the 21 st century. London: Fourth Estate. 
Lewin, A. Y., Kenney, M., \& Murmann, J. P. (Eds). 2016. China's innovation challenge: Overcoming the middle-income trap. Cambridge: Cambridge University Press.

Lewin, A. Y., \& Volberda, H. W. 1999. Prolegomena on coevolution: A framework for research on strategy and new organizational forms. Organization Science, 10(5): 519-534.

Lewin, A. Y., \& Volberda, H. W. 2011. Co-evolution of global sourcing: The need to understand the underlying mechanisms of firm-decisions to offshore. International Business Review, 20(3): 241-251.

Li, J., Meyer, K. E., Zhang, H., \& Ding, Y. 2017. Diplomatic and corporate networks: Bridges to foreign locations. Journal of International Business Studies. https://doi.org/10.1057/ s41267-017-0098-4.

Luo, Y., \& Tung, R. L. 2007. International expansion of emerging market enterprises: A springboard perspective. Journal of International Business Studies, 38(4): 481-498.

Luo, Y., \& Tung, R. L. 2018. A general theory of springboard MNEs. Journal of International Business Studies, 49(2): 129-152.

MacDonald, L. 2002. Globalization and social movements: Comparing women's movements responses to NAFTA in Mexico, the USA and canada. International Feminist Journal of Politics, 4(2): 151-172.

Maggi, G. 1999. The role of multilateral institutions in international trade cooperation. American Economic Review, 89(1): 190-214.

Mahoney, J., \& Thelen, K. 2009. Explaining institutional change: Ambiguity, agency, and power. Cambridge: Cambridge University Press.

Mannheim, K. 1936. Ideology and utopia: An introduction to the sociology of knowledge. New York: Harcourt, Brace, \& World.

Matten, D., \& Moon, J. 2008. "Implicit" and "explicit" CSR: A conceptual framework for a comparative understanding of corporate social responsibility. Academy of Management Review, 33(2): 404-424.

Matthews, E. G., \& Callaway, R. L. 2017. International relations theory: A primer. Oxford: Oxford University Press.

McCormick, J. 2007. The European superpower. Houndsmills: Palgrave Macmillan.

Meyer, K. E. 2017. International business in an era of antiglobalization. Multinational Business Review, 25(2): 78-90.

Meyer, K. E., \& Sinani, E. 2009. When and where does foreign direct investment generate positive spillovers? A meta-analysis. Journal of International Business Studies, 40(7): 1075-1094.

Milberg, W., \& Winkler, D. 2010. Economic insecurity in the new wave of globalization: Offshoring and the labor share under varieties of capitalism. International Review of Applied Economics, 24(3): 285-308.

Miska, C., Witt, M. A., \& Stahl, G. K. 2016. Drivers of global CSR integration and local CSR responsivness: Evidence from Chinese MNEs. Business Ethics Quarterly, 26(3): 317-345.

Moon, H. C., Rugman, A. M., \& Verbeke, A. 1998. A generalized double diamond approach to the global competitiveness of Korea and Singapore. International Business Review, 7(2): 135-150.

Moravcsik, A. 1997. Taking preferences seriously: A liberal theory of international politics. International Organization, 51(4): 513-553.

North, D. C. 1990. Institutions, institutional change and economic performance. Cambridge: Cambridge University Press.

Nye, J. S. 1990. Soft power. Foreign Policy, 80: 153-171.

Nye, J. S., Jr. 2015. Is the American century over?. Cambridge, MA: Polity.

O'Mara, M. P. 2015. Cities of knowledge: Cold war science and the search for the next Silicon Valley. Princeton, NJ: Princeton University Press.

O'Rourke, K. H., \& Williamson, J. G. 2014. Introduction: The spread of and resistance to global capitalism. In L. Neal \& J. G. Williamson (Eds), The Cambridge history of capitalism: The spread of capitalism: From 1848 to the present: 1-21. Cambridge: Cambridge University Press.

OECD. 2017. Towards a better globalisation: How Germany can respond to the critics. Paris: OECD.

Oliver, C. 1991. Strategic responses to institutional processes. Academy of Management Review, 16(1): 145-179.

Organski, A. F. K. 1958. World politics. New York: Knopf.

Packenham, R. A. 1992. The dependency movement: Scholarship and politics in development studies. Cambridge, MA: Harvard University Press.

Pettman, J. J. 2004. Feminist international relations after 9/11. The Brown Journal of World Affairs, 10(2): 85-96.

Pevehouse, J. C., \& Goldstein, J. S. 2016. International relations (11th ed.). London: Pearson.

Pfeffer, J., \& Salancik, G. R. 1978. The external control of organizations: A resource dependence perspective. Stanford, CA: Stanford University Press.

Polanyi, K. 1944. The great transformation. New York: Farrar \& Rinehart.

Ramamurti, R. 2004. Developing countries and MNEs: Extending and enriching the research agenda. Journal of International Business Studies, 35(4): 277-283.

Rathert, N. 2016. Strategies of legitimation: MNEs and the adoption of CSR in response to host-country institutions. Journal of International Business Studies, 47(7): 858-879.

Redding, G., \& Witt, M. A. 2007. The future of Chinese capitalism: Choices and chances. Oxford: Oxford University Press.

Rodrik, D. 2018. Populism and the economics of globalization. Journal of International Business Policy, 1(1): 12-33.

Ruggie, J. G. 1982. International regimes, transactions, and change: Embedded liberalism in the postwar economic order. International Organization, 36(2): 379-415.

Ruggie, J. G. 1983. Continuity and transformation in the world polity: A neorealist synthesis. World Politics, 35(2): 261-285.

Ruggie, J. G. 1998. What makes the world hang together? Neoutilitarianism and the social constructivist challenge. International Organization, 52(4): 855-885.

Rugman, A. M., \& D'Cruz, J. R. 1993. The "double diamond" model of international competitiveness: The Canadian experience. MIR Management International Review, 33(2): 17-39.

Rugman, A. M., \& Verbeke, A. 2004. A perspective on regional and global strategies of multinational enterprises. Journal of International Business Studies, 35(1): 3-18.

Santos, B. S. 2013. The rise of the global left: The world social forum and beyond. London: Zed Books.

Schneider, M. R., Schulze-Bentrop, C., \& Paunescu, M. 2010. Mapping the institutional capital of high-tech firms: A fuzzyset analysis of capitalism variety and export performance. Journal of International Business Studies, 41(2): 246-266.

Shadlen, K. 2008. Globalisation, power and integration: The political economy of regional and bilateral trade agreements in the Americas. The Journal of Development Studies, 44(1): $1-20$.

Stockholm International Peace Research Institute. 2018. SIPRI military expenditure database. https://www.sipri.org/ databases/milex. Accessed January 7, 2019.

Stolper, W. F., \& Samuelson, P. A. 1941. Protection and real wages. The Review of Economic Studies, 9(1): 58-73.

Subramanian, A. 2011. Is China already number one? New GDP estimates. https://piie.com/blogs/realtime-economic-issueswatch/china-already-number-one-new-gdp-estimates. Accessed October 26, 2017.

Sun, P. 2019. Corporate political ties in emerging markets. In R. Grosse \& K. E. Meyer (Eds), The Oxford handbook of management in emerging markets291-310. Oxford: Oxford University Press.

Verbeke, A., Coeurderoy, R., \& Matt, T. 2018. The future of international business research on corporate globalization that never was.... Journal of International Business Studies, 49(9): 1101-1112. 
Verhofstadt, G. 2006. The United States of Europe. London: The Federal Trust for Education \& Research.

Wade, R. 1990. Governing the market: Economic theory and the role of government in East Asian industrialization. Princeton, NJ: Princeton University Press.

Wagner, C. Z. 2011. Looking at regional trade agreements through the lens of gender. Saint Louis University Public Law Review, 31: 497-537.

Walker, C., \& Ludwig, J. 2017. The meaning of sharp power. https://www.foreignaffairs.com/articles/china/2017-11-16/ meaning-sharp-power. Accessed June 22, 2018.

Wallerstein, I. 1980. The modern world system. New York: Academic.

Waltz, K. N. 1979. Theory of international politics. Reading, MA: Addison-Wesley.

Webber, D. 2016. Declining power Europe? The evolution of the European union's world power in the early 21st century. European Review of International Studies, 3(1): 31-52.

Williamson, O. E. 1985. The economic institutions of capitalism: Firms, markets, relational contracting. New York: The Free Press.

Witt, M. A. 2016. The road ahead for China: Implications from south Korea's experience. In A. Y. Lewin, M. Kenney, \& J. P. Murmann (Eds), China's innovation challenge: Overcoming the middle income trap: 87-107. Cambridge: Cambridge University Press.

Witt, M. A., \& Jackson, G. 2016. Varieties of capitalism and institutional comparative advantage: A test and reinterpretation. Journal of International Business Studies, 47(7): 778-806.
Witt, M. A., Kabbach de Castro, L. R., Amaeshi, K., Mahroum, S., Bohle, D., \& Saez, L. 2018. Mapping the business systems of 61 major economies: A taxonomy and implications for varieties of capitalism and business systems research. SocioEconomic Review, 16(1): 5-38.

Witt, M. A., \& Lewin, A. Y. 2007. Outward foreign direct investment as escape response to home country institutional constraints. Journal of International Business Studies, 38(4): 579-594.

Witt, M. A., \& Redding, G. 2014. China: Authoritarian capitalism. In M. A. Witt \& G. Redding (Eds), The Oxford handbook of Asian business systems: 11-32. Oxford: Oxford University Press.

World Bank. 2017. World development indicators. https://data. worldbank.org/data-catalog/world-development-indicators. Accessed August 21 and October 14, 2017.

World Bank. 2018. World development indicators. https://data. worldbank.org/data-catalog/world-development-indicators. Accessed June 19, 2018.

Yang, X., \& Rivers, C. 2009. Antecedents of CSR practices in MNCs' subsidiaries: A stakeholder and institutional perspective. Journal of Business Ethics, 86(2): 155-169.

Zimmermann, A., \& Bollbach, M. F. 2015. Institutional and cultural barriers to transferring lean production to China: Evidence from a German automotive components manufacturer. Asian Business \& Management, 14(1): 53-85.

See Tables 2 and 3.

\section{APPENDIX}

Table 2 US GDP at purchasing power parity and in constant 2011 international dollars relative to the next largest economy and the world. Peak year indicated in bold. Source: World Bank (2018)

\begin{tabular}{|c|c|c|}
\hline & US relative to world (\%) & US relative to next largest (\%) \\
\hline 1990 & 19.6 & 244.9 \\
\hline 1991 & 19.3 & 236.6 \\
\hline 1992 & 19.6 & 243.0 \\
\hline 1993 & 19.8 & 250.9 \\
\hline 1994 & 20.0 & 258.5 \\
\hline 1995 & 19.9 & 258.4 \\
\hline 1996 & 19.9 & 260.2 \\
\hline 1997 & 20.0 & 269.0 \\
\hline 1998 & 20.4 & 284.1 \\
\hline 1999 & 20.6 & 289.4 \\
\hline 2000 & 20.5 & 277.7 \\
\hline 2001 & 20.2 & 258.8 \\
\hline 2002 & 20.0 & 241.4 \\
\hline 2003 & 19.8 & 225.5 \\
\hline 2004 & 19.5 & 212.6 \\
\hline 2005 & 19.3 & 197.2 \\
\hline 2006 & 18.8 & 179.6 \\
\hline 2007 & 18.1 & 160.0 \\
\hline 2008 & 17.6 & 145.5 \\
\hline 2009 & 17.2 & 129.3 \\
\hline 2010 & 16.7 & 119.9 \\
\hline 2011 & 16.3 & 111.2 \\
\hline 2012 & 16.1 & 105.4 \\
\hline
\end{tabular}


Table 2 (Continued)

US relative to world (\%)

\begin{tabular}{lcc} 
& US relative to next largest (\%) \\
\hline 2013 & 15.9 & 99.4 \\
2014 & 15.7 & 95.0 \\
2015 & 15.7 & 91.5 \\
2016 & 15.4 & 87.0 \\
2017 & 15.2 & 83.2
\end{tabular}

Table 3 US military spending relative to the next largest spender and the world. Peak year indicated in bold. Source: Stockholm International Peace Research Institute, 2018

\begin{tabular}{|c|c|c|}
\hline & US relative to world (\%) & US relative to next largest (\%) \\
\hline 1988 & 42.7 & 244.7 \\
\hline 1989 & 42.2 & 261.1 \\
\hline 1990 & 41.8 & 294.9 \\
\hline 1991 & 45.8 & 844.8 \\
\hline 1992 & 46.4 & 921.7 \\
\hline 1993 & 45.5 & 883.0 \\
\hline 1994 & 44.4 & 828.6 \\
\hline 1995 & 43.8 & 820.9 \\
\hline 1996 & 42.2 & 795.3 \\
\hline 1997 & 41.2 & 788.5 \\
\hline 1998 & 40.7 & 791.3 \\
\hline 1999 & 39.8 & 786.6 \\
\hline 2000 & 40.0 & 826.6 \\
\hline 2001 & 39.5 & 835.8 \\
\hline 2002 & 41.5 & 821.1 \\
\hline 2003 & 44.2 & 865.3 \\
\hline 2004 & 45.2 & 853.0 \\
\hline 2005 & 45.5 & 807.5 \\
\hline 2006 & 44.8 & 709.8 \\
\hline 2007 & 44.2 & 651.0 \\
\hline 2008 & 45.0 & 638.4 \\
\hline 2009 & 45.4 & 569.4 \\
\hline 2010 & 45.9 & 556.7 \\
\hline 2011 & 45.3 & 509.3 \\
\hline 2012 & 42.9 & 442.4 \\
\hline 2013 & 40.1 & 372.6 \\
\hline 2014 & 37.6 & 322.2 \\
\hline 2015 & 36.8 & 295.2 \\
\hline 2016 & 36.6 & 277.8 \\
\hline 2017 & 36.1 & 261.7 \\
\hline
\end{tabular}

\section{ABOUT THE AUTHOR}

Michael A. Witt is Affiliate Professor of Strategy and International Business at INSEAD. He earned his $\mathrm{PhD}$ at Harvard University and explores national institutions and their impact on managerial and organizational outcomes. His papers have appeared in journals such as JIBS, SMJ, JMS, BEQ, $J B E, M O R$, and SER. He has published four scholarly books, including The Oxford Handbook of Asian Business Systems (with Gordon Redding). (c) (i) $\odot$ This article is licensed under a CreaBY NC No tive Commons Attribution-NonCommercial-NoDerivatives 4.0 International License, which permits any non-commercial use, sharing, distribution and reproduction in any medium or format, as long as you give appropriate credit to the original author(s) and the source, and provide a link to the Creative Commons licence. You do not have permission under this licence to share adapted 
material derived from this article or parts of it. The images or other third party material in this article are included in the article's Creative Commons licence, unless indicated otherwise in a credit line to the material. If material is not included in the article's Creative Commons licence and your intended use is not permitted by statutory regulation or exceeds the permitted use, you will need to obtain permission directly from the copyright holder. To view a copy of this licence, visit http:// creativecommons.org/licenses/by-nc-nd/4.0/.

Publisher's Note Springer Nature remains neutral with regard to jurisdictional claims in published maps and institutional affiliations.

Accepted by Klaus Meyer, Area Editor, 9 January 2019. This article has been with the author for three revisions. 